\title{
Inscribing Votive Offerings and Tamata: Narratives, Artefacts, Asklepios, and Panagia Megalochari
}

\begin{abstract}
Steven M. Oberhelman*
Divine miracle healing in the ancient and modern worlds is extensively documented through historical and literary texts, votive offerings, inscriptions, and miracle stories. In this article I focus on the votive inscriptions at the temple complex of the healing god Asklepios at Epidauros, and the miracle stories at the Church of Panagia Megalochari ${ }^{1}$ on the Greek island of Tinos, and how they were crafted to tell a narrative of healing not only to accompany the votive offerings, but also to reimagine those offerings by providing a written framework that was previously assumed or was lacking. The purpose of the stories, which usually date after the offerings that they describe, is to position the gifts within a narrative of faith and socio-cultural discourse. The written texts, preserving what were originally private stories and/or oral traditions, function as a public narrative and allow their reader to reimagine, amplify, and reinterpret the visual gifts as manifestations of the power of the healing god Asklepios or the healing grace of Panagia Megalochari.
\end{abstract}

\section{Votive Gift Traditions in Ancient and Byzantine Greece}

The tradition of votive gifts in classical and Byzantine Greece is well-known and amply documented in scholarship, and so only a few introductory words are needed. ${ }^{2}$ The ancient Greeks believed that the gods possessed the power to heal, and so the ill visited their sanctuaries in order to seek a cure for ailments. The chief healing god in antiquity was Asklepios. ${ }^{3}$ In his cult suppliants, after

*Professor of Classics, Holder of the George Sumey Jr Endowed Professorship of Liberal Arts, and Associate Dean, Texas A\&M University, USA.

1. Panagia describes Mary, the mother of Jesus; the adjective Megalochari means "of great grace."

2. See Oberhelman for bibliography. [Steven M. Oberhelman, "Anatomical Votive Reliefs as Evidence for Specialization at Healing Sanctuaries in the Ancient Mediterranean World," Athens Journal of Health 1 (2014): 47-62]. Numerous articles on votive gifts may be found at https://thevotivesproject.org/.

3. Rudolf Herzog, Die Wunderheilungen von Epidauros: Ein Beitrag zur Geschichte der Medizin und der Religion (The Miracle Healing of Epidaurus: A Contribution to the History of Medicine and Religion) (Leipzig: Dieterichsche Verlagsbuchhandlung, 1931); Folkert T. van Straten, "Gifts for the Gods," in Faith, Hope and Worship. Aspects of Religious Mentality in the Ancient World, ed. Henk S. Versnel (Leiden: Brill, 1981), 65-151; Emma Edelstein and Ludwig Edelstein, Asclepius: A Collection and Interpretation of the Testimonies, 2 vols (Baltimore: Johns Hopkins University Press, 1988). [First edition: Baltimore: Johns Hopkins University Press, 1945]; Jürgen Reithmüller, Asklepios: Heiligtümer und Kulte (Asklepios: 
preliminary sacrifices and purification, slept at night in a sleeping chamber, called abaton (Figures 1 and 2). Asklepios then visited the sick person and healed her either by direct intervention (laying on of hands, applying medicines, even performing surgery) or indirectly (sending a dream that included instructions for a treatment upon awakening). Many instructions in dream-inspired cures reflected contemporary medicine: phlebotomy, baths, diet, exercise, poultices, compound drugs made of plants and herbs, and emetics. ${ }^{4}$

\section{Figure 1. Sanctuary of Asklepios, Epidauros ${ }^{5}$}

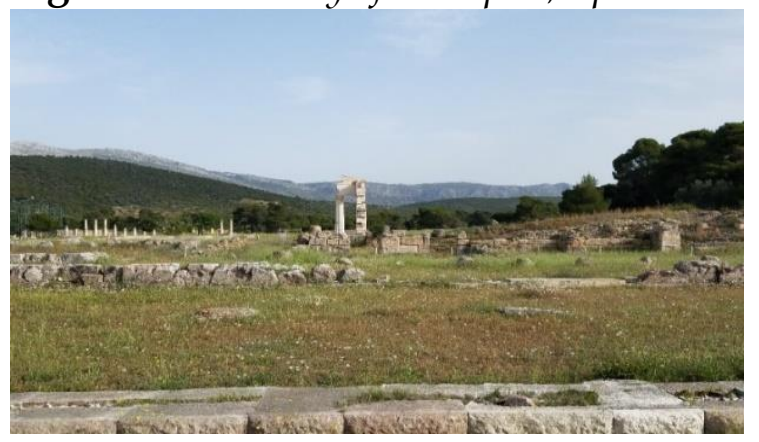

sanctuaries and cults), 2 vols (Heidelberg: Verlag Archäologie und Geschichte, 2005); Bronwen L. Wickkiser, Asklepios, Medicine and the Politics of Healing in Fifth-Century Greece: Between Craft and Cult (Baltimore: Johns Hopkins University Press, 2008); Henk Versnel, Coping with the Gods: Wayward Readings in Greek Theology (Leiden: Brill, 2011).

4. Philip van der Eijk, "Divination, Prognosis and Prophylaxis: The Hippocratic Work 'On Dreams' (De Victu 4) and Its Near Eastern Background," in Magic and Rationality in Ancient Near Eastern and Graeco-Roman Medicine, ed. Herman Horstmanshotl and Marten Stol (Leiden: Brill, 2004), 187-218; Mileni Melfi, Il santuari di Asclepio in Grecia. Studia Archaeologica (The sanctuary of Asclepius in Greece. Studia Archaeologica), no. 157 (Roma: L'Erma di Bretschneider, 2007); Gil H. Renberg, Where Dreams May Come: Incubation Sanctuaries in the Greco-Roman World, 2 vols, Religions in the Graeco-Roman World, no. 184 (Leiden: Brill, 2017), vol. I: 113-270; Florian Steger, Asklepios: Medizin und Kult (Asklepios: Medicine and Cult) (Stuttgart: Franz Steiner Verlag, 2017). Not all cures were done through incubation or temple-sleep, and incubation was not always practiced at healing sanctuaries; see Renberg, "Was Incubation Practiced in the Latin West?," Archiv für Religionsgeschichte 8 (2016): 104-147.

5. All photographs in this article are my own. 
Figure 2. The Sanctuary of Asklepios, Epidauros; the Abaton (Sleeping Chamber) on Right; Looking from the Ruins of the Temple of Asklepios

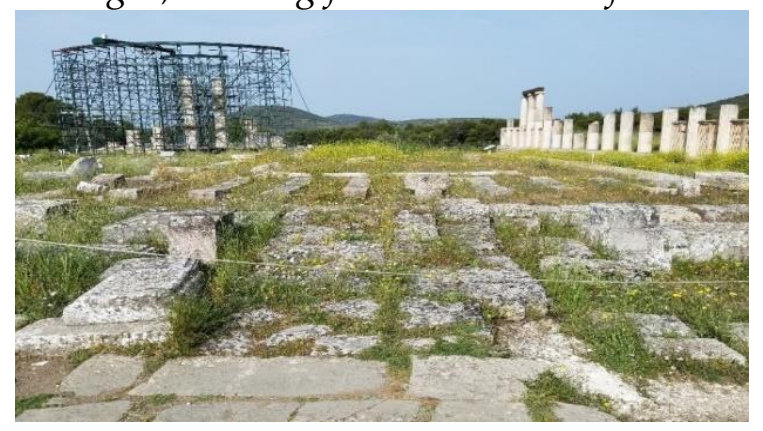

Archaeologists have recovered at ancient Greek healing shrines numerous anatomical votive reliefs, made from marble, wood, stone, or terracotta. The votives were dedicated by grateful patients and typically portrayed the body part that had been healed. Figure 3, from the sanctuary of Epidaurus, depicts a votive that a Cutius from Gaul dedicated in return for the restoration of his hearing. ${ }^{6}$

Figure 3. Votive of Clutius of Gaul, Epidauros Museum

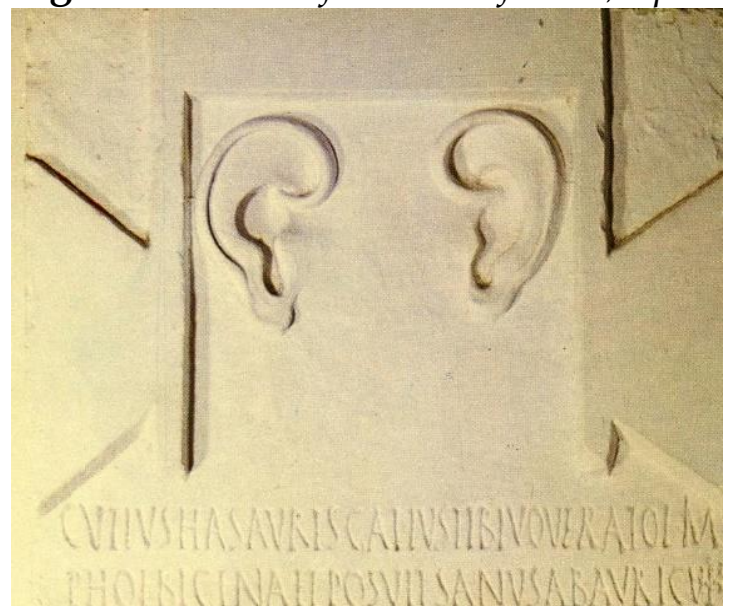

Although it cannot be proved conclusively, the numbers and types of body parts represented on surviving votive offerings in a given sanctuary may reflect

6. The number of votives at Epidauros are very few. This may be a local tradition or there is a hidden cache somewhere in a field nearby. Corinth and Athens, the two other important mainland Asklepian centers, have a number of votives, but of different types: at Corinth, terracotta votives made from the local soil; at Athens, stone reliefs. See, Lynn R. LiDonnici, Tale and Dream: The Text and Compositional History of the Corpus of Epidaurian Miracle Cures (doctoral thesis, University of Pennsylvania, 1989), 137-140; and LiDonnici, The Epidaurian Miracle Inscriptions: Text, Translation and Commentary. Texts and Translations, no. 36 (Atlanta: Society of Biblical Literature, 1995), 41-43, for discussion. 
specialization. ${ }^{7}$ At the sanctuary of Asklepios in the city of Corinth, numerous votive offerings depict appendages and limbs-hands and feet, arms and legs; for example, there are alone are 145 hands $^{8}$ (Figure 4). Since many of the suppliants visiting the Corinth sanctuary would have had an agricultural and rural lifestyle that involved much walking, working in the fields, and using equipment and farming implements, the votives may explain the high number of feet offerings (ankle sprains and foot injuries), and the high number of hand offerings (injuries, wounds, and bites). Likewise the many votives of male genitalia at the Corinth sanctuary may be related to the extensive sex trade of the city. At the sanctuary of Asklepios in Athens, $40 \%$ of all votive offerings are eyes (154 in total). ${ }^{9}$ Overall, ailments associated with the head or parts of it seem to have been a major concern for the suppliants. Besides the 154 eyes, we have 25 ears (13 single ears, and six pairs) and 17 faces; the faces are harder to interpret, since the ailment that was healed could have been something simple like erysipelas or a more serious problem like sinus infection.

Figure 4. Votive Offerings, Corinth Museum

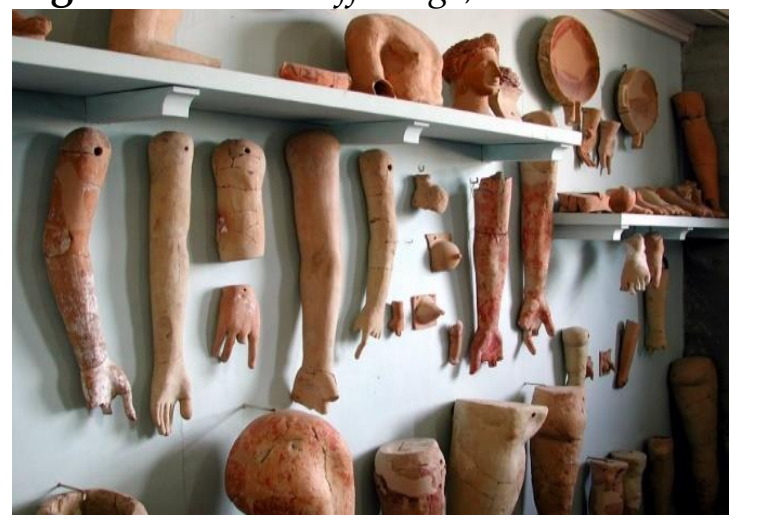

In the Byzantine centuries of Greece, miraculous temple cures continued, but

7. Graham casts doubts on claims of specialization, at least for Greece; given the paucity of remains, she may be correct (contra, Oberhelman, "Anatomical Votive Reliefs"). The Italian sanctuaries, however, were likely specialized, given the immense number of artefacts recovered at these sites; for an introduction to these sanctuaries, see the bibliography in Oberhelman ("Anatomical Votive Reliefs"). [Emma-Jayne Graham, "Anatomical Votive Reliefs as Proof for Specialisation at Ancient Greek Healing Sanctuaries?," The Votives Project. Last modified May 4, 2017, retrieved from https://bit.ly/ 2wj2U9O].

8. Carl Roebuck, Corinth, Volume XIV: The Asklepieion and Lerna (Princeton: American School of Classical Studies at Athens, 1951).

9. Sara B. Aleshire, The Athenian Asklepieion: Their People, Their Dedications, and Their Inventories (Amsterdam: J. C. Gieben, 1989); Björn Forsen, Griechische Gliederweihungen. Eine Untersuchung zu ihrer Typologie und ihrer religions- und sozialgeschichtlichen Bedeutung (Greek link consecrations. An investigation on their typology and its religious and social historical significance) (Helsinki: Papers and Monographs of the Finnish Institute at Athens, 1996). 
the pagan temples and healing centers had become Christian sanctuaries where Jesus, Panagia, and saints carried out miracle cures..$^{10}$ For example, the Church of the saints Cosmas and Damian in Constantinople became the site of numerous miracles and cures for the faithful who slept in its porticoes and atrium. The emperor Justinian the Great (482-565) was cured at this church through a dream. ${ }^{11}$ Cosmas and Damian's fame spread throughout Greece and Crete; the old Asklepian sanctuary on the south slope of the Athenian acropolis was converted in the fifth or sixth century into a healing shrine for the pair. Just as Asklepios had done, the saints conducted business by appearing in a patient's dream. The saints either cured with medications and surgery, or gave instructions for a cure that the patient was to follow the next day. ${ }^{12}$

Another famous pair of healing saints, Cyrus and John, healed worshippers through personal touch or by prescribing remedies in dreams..$^{13}$ The cult was based originally in Egypt, but in the seventh century moved to Constantinople. Other famous sites of church healing were, in Western Turkey, the shrine of Saint Artemios, and, in Syria, the shrine of Saint Simeon the Younger near Antioch and the shrine of Saint Thecla. ${ }^{14}$ Scores of holy places in the Byzantine Empire were dedicated to miracle cures, proving that healing at night in sacred places was a very important part of Byzantine religion and society. ${ }^{15}$

10. Anne-Marie Talbot, "Pilgrimage to Healing Shrines: The Evidence of Miracle Accounts," Dumbarton Oaks Papers 56 (2002): 153-173; Derek Krueger, "Christian Piety and Practice in the Sixth Century," in The Cambridge Companion to the Age of Justinian, ed. Michael Maas (Cambridge: Cambridge University Press, 2005), 291-315; John T. Chirban (ed.), Holistic Healing in Byzantium (Brookline, MA: Holy Cross Orthodox Press, 2010); Oberhelman (ed.) Dreams, Healing, and Medicine in Greece: From Antiquity to the Present (London: Ashgate, 2013), chaps. 7-9; Robert Wisniewski, The Beginnings of the Cult of Relics (Oxford: Oxford University Press, 2018).

11. Stephanos Efthymiadis, Vincent Déroche, with contributions by André Binggeli and Zissis Aïnalis, "Greek Hagiography in Late Antiquity (Fourth-Seventh Centuries)," in The Ashgate Research Companion to Byzantine Hagiography, Vol. 1: Periods and Places, ed. Sthephanos Efthymiadis (Aldershot: Ashgate, 2011), 35-94.

12. Ludwig Deubner, De incubatione capita quattuor (Four books concerning incubation) (Leipzig and Berlin: Teubner, 1900), 68-79; Deubner, Kosmas und Damian: Texte und Einleitung (Kosmas and Damian: Texts and Introduction) (Leipzig and Berlin: Teubner, 1907).

13. John Duffy, "Some Observations on Sophronius' Miracles of Cyrus and John," Journal of Theological Studies 35 (1984): 71-90.

14. Virgil S. Crisafulli and John W. Nesbitt, The Miracles of St. Artemios (Leiden: Brill, 1996).

15. Ildiko Csepregi, The Compositional History of Greek Christian Incubation Miracle Collections: Saint Thecla, Saint Cosmas and Damian, Saint Cyrus and John, Saint Artemios (doctoral dissertation, Central European University, 2007). This doctoral work is slated to be published soon by Cambridge University Press. See also Renberg (Where Dreams May Come, vol. II: 743-807), for a phenomenally comprehensive bibliographical survey on early and mid-Byzantine church healing. 


\section{The Church of Panagia Megalochari}

At the Church of Panagia Megalochari on the Greek island of Tinos (Figure 5), the ancient and Byzantine Christian traditions of votive offerings and sacred healing survive. The Church of Panagia has been the site of many miracles ever since it was built in 1824 . The belief that miracles happen at the church is so widespread that many thousands of pilgrims come to the site every year (estimates are up to 200,000 people). Oftentimes pilgrims begin with a preliminary visit to the church to request healing or protection for themselves or for a loved one, and make a vow (tama). In return the pilgrim promises to bring back their tamata (votive offering). ${ }^{16}$ It is not uncommon for a pilgrim to approach the church on her knees (Figure 6) on the Leôforos Megalocharês, the road that starts at the harbor and concludes at the entrance to the sanctuary (Figure 7).

Figure 5. Church of Panagia Megalochari, Tinos

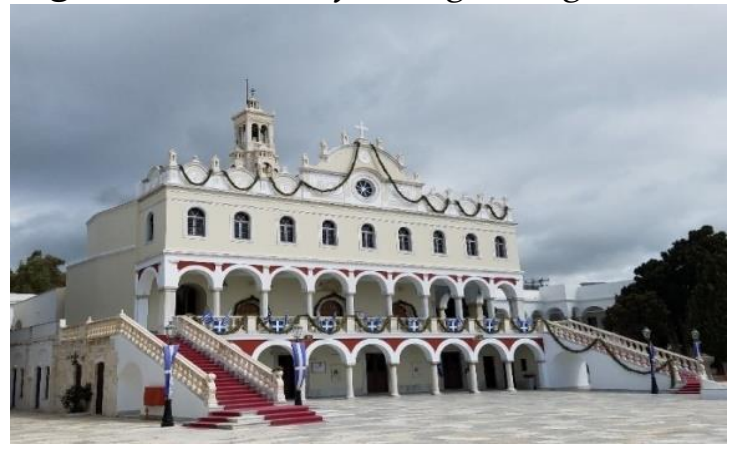

Figure 6. Pilgrim Making His Way to the Church of Panagia Megalochari from Tinos Harbor

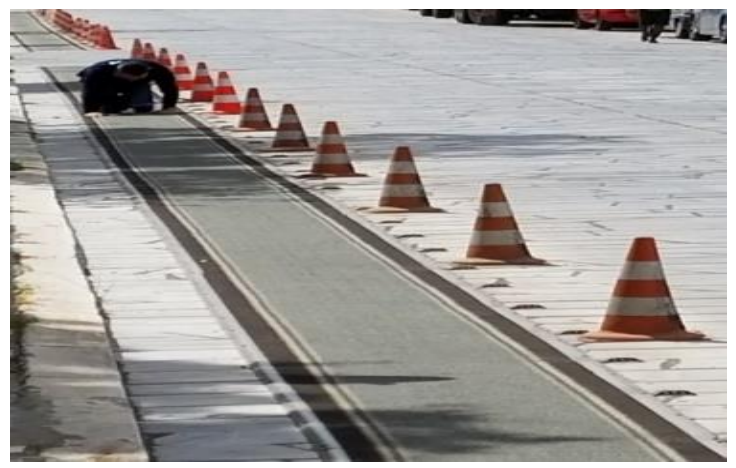

16. Jill Dubisch, "Golden Oranges and Silver Ships: An Interpretive Approach to a Greek Holy Shrine," Journal of Modern Greek Studies 6 (1988): 117-134; Evy Johanne Håland, "The Dormition of the Virgin Mary, on the Island of Tinos: A Performance of Gendered Values in Greece," The Journal of Religious History 36 (2012): 95. 
Figure 7. Leôforos Megalocharês from the Courtyard of the Church of Panagia Megalochari down to the Harbor of Tinos

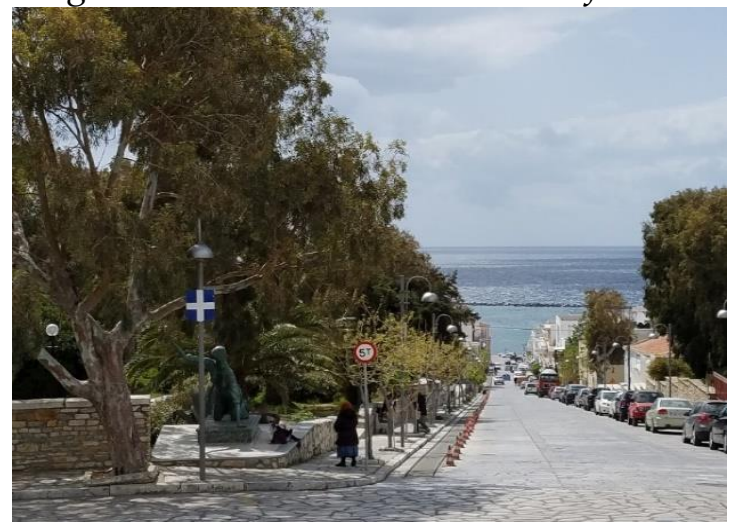

The sanctuary grounds are laid out in a way similar to Asklepios's sanctuary at Epidaurus, which had nighttime facilities for visitors, facilities for festivals, banquet areas, the main temple, and then an area where the ill could sleep at night and receive a cure. Next door to the Church of Panagia Megalochari are offices where pilgrims can leave their votive tamata to Panagia. Guesthouses are located on the eastern side of the complex, and pilgrims may stay free of charge for up to three days. On the same side is a reception hall where banquets occur. I should note that it is not uncommon for pilgrims to sleep inside the church as well, just as they did at Epidaurus 2,500 years earlier.

Figure 8. (Left) Tamata for Sale along the Leôforos Megalocharês, Tinos; (right) Two Personal Purchases: a Leg Votive and a Bottle for Collecting Holy Water (Agíasma)

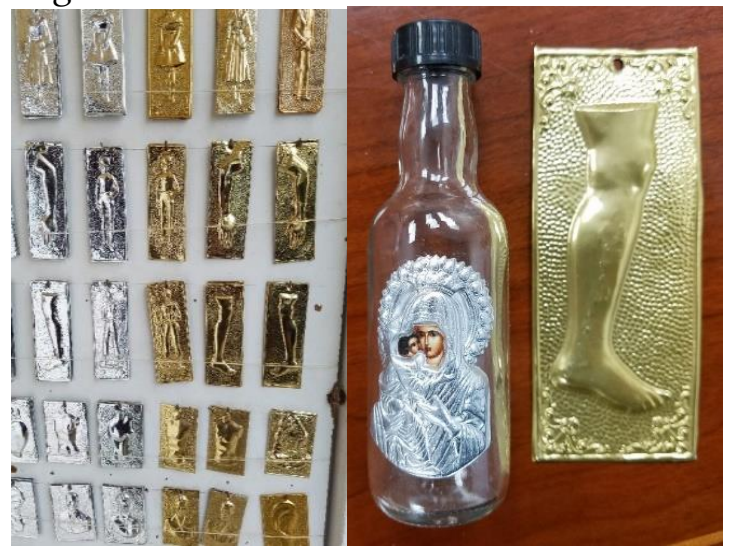

At the center of the Tinos sanctuary is the Church of Panagia Megalochari, a three-aisled basilica with a cupola over the Holy Altar. When entering the church, to the left of the entrance, one sees the iconostasis containing the miraculous icon of Panagia. The icon is surrounded by votive offerings (tamata) left by pilgrims as 
offerings of thanksgiving for answered prayers. ${ }^{17}$ Tamata can be purchased at shops on the island (Figure 8 ), although they may be found in many places like Athens. They are rectangular pieces of metal with miniature figures shaped on them. Made of tin, or even silver or gold, the figures range from ears to ankles and fingers to houses and animals to stefana. ${ }^{18}$ In antiquity votives were massproduced or were made on specification. The former is more typical, and that tradition has not changed. One difference is that the Tinos votives are not limited to healing, as in antiquity. Grateful pilgrims now offer votives for preservation of boats (or successful fishing), for safety while serving as a soldier, for a romantic relationship, or for safety of one's animals. Some tamata hang from the church's ceiling (Figure 9), but not all are on public display. Most tamata are simply stored away or are sold. Natural products like olive oil or costly items like jewelry are sold, the proceeds used for humanitarian causes. ${ }^{19}$

Figure 9. Votive Offerings Hanging from the Ceiling of the Church of Panagia Megalochari, Tinos

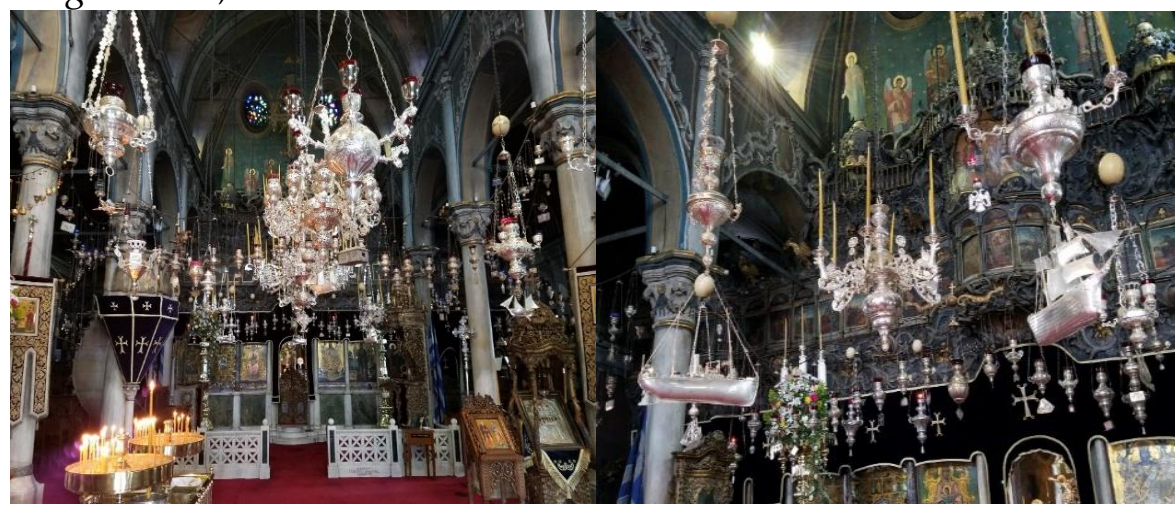

\section{The Holy Icon of Panagia Megalochari}

The discovery of the icon of Panagia Megalochari began in $1821 . .^{20}$ Panagia

17. Pilgrims come for the icon or for the Panagia; since some pilgrims feel that the Panagia resides in the icon, the icon and the Panagia may be considered one and the same. [Dubisch, "Men's Time and Women's Time: History, Myth, and Ritual at a Modern Greek Shrine," Journal of Ritual Studies 5 (1991): 8-9].

18. Stefana are two wedding crowns that are linked together by a ribbon and express the joining of two souls and the creation of a new household.

19. Dubisch, "Men's Time and Women's Time, 20 note 22.

20. Dubisch, "Pilgrimage and Popular Religion at a Greek Holy Shrine," in Religious Orthodoxy and Popular Faith in European Society, ed. Ellen Badone (Princeton: Princeton University Press, 1990), 113-139; Dubisch, "Men's Time and Women's Time, 4-6; Håland, "The Dormition of the Virgin Mary, 92-94; Håland, Greek Festivals, Modern and Ancient: A Comparison of Female and Male Values, 2 vols (Newcastle upon Tyne: Cambridge Scholars

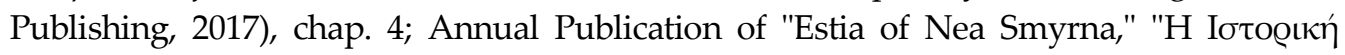

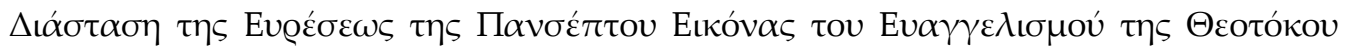


appeared in a dream to a Michalis Polizois, a native of Tinos, ${ }^{21}$ and gave him specific instructions: He was to dig on the farm of Antonios Doxaras. Polizois proceeded to dig but gave up when he discovered only the remains of a Romanera wall.

The following year, Pelagia, a nun and the daughter of the priest Nikiforos Negreponti, received a vision of Panagia in which the same location was communicated. ${ }^{22}$ The nun, however, was not told to dig at the site, as the male Polizois had been instructed; rather, she was to go and convince Stamatelos

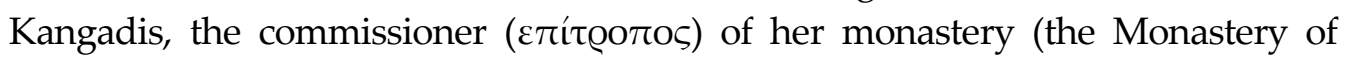
Kechrovouni), to organize a new dig at Doxaras's farm. Pelagia ignored the dream since it seemed unbelievable that Panagia would appear to her, and she was aware that sometimes Satan sends false dreams to lead astray the faithful.

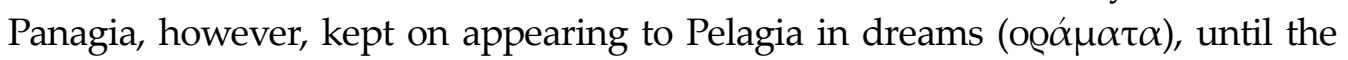
nun was finally convinced that the dreams were divine in origin. She decided to share her visions with Gabriel the local bishop. He assembled the clergy, authorities, and the local population and persuaded them to resume digging on the farm.

Excavations began in earnest in September 1822, and after only a few days of digging and at about 20 meters in depth, the early Byzantine church, the Church of Saint John the Precursor (Prodromos), was discovered. The icon, however, was not found and so people lost the enthusiasm to continued digging. Work stopped, and many locals accused Pelagia of lying about the icon. However, a cholera epidemic broke out, resulting in many deaths. Locals feared that the epidemic was caused by Panagia's anger at the cessation of excavations, and so Kangadis resumed excavations on 25 November 1822. On the very first day of work, a well suddenly filled with water, a miracle as it was claimed. The well was later given its own church, the Church of Zôodochos Pigi (Life-Giving Well), which was constructed from the remains of the older church (Figure 10).

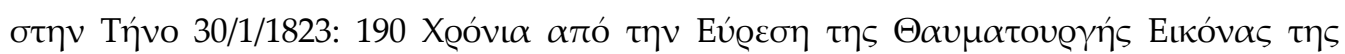

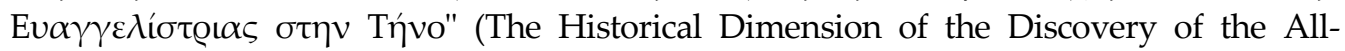
Venerable Icon of the Annunciation of the Theotokos on Tinos 30 January 1823: 190 Years

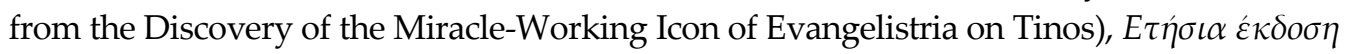

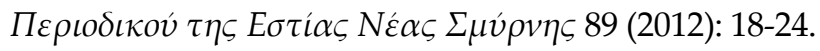

21. Kangadis gives the earliest account of these events. [Dimitrios Kangadis, Ev́ $\rho \varepsilon \sigma \iota \varsigma$

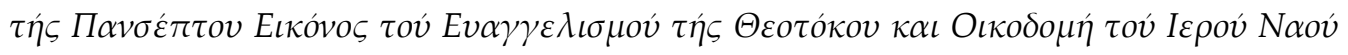
$\tau \eta \dot{~ E v ~ E \gamma \gamma \gamma \varepsilon \lambda \iota \sigma \tau \rho i \alpha \varsigma ~ \varepsilon ı \varsigma ~ \tau \eta v ~ N i ́ \sigma o v ~ T i ́ v o v ~(D i s c o v e r y ~ o f ~ t h e ~ A l l-V e n e r a b l e ~ I c o n ~ o f ~ t h e ~}$ Annunciation of the Mother of God and the Establishment of the Holy Church of Evangelistria on

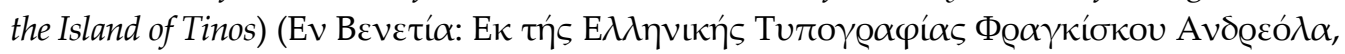
1833)].

22. Dubisch offers a good biography of this nun. [Dubisch, In a Different Place: Pilgrimage, Gender, and Politics at a Greek Island Shrine (Princeton: Princeton University Press, 1995), 149-152]. 
Figure 10. Church of Zôodochos Pigi, Tinos; Holy Water (Agíasma) is Dispensed from the White Fountain on the Left

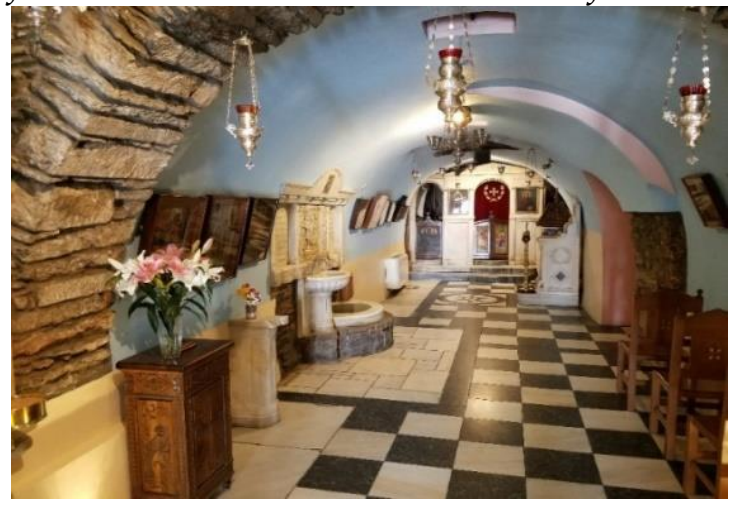

On 30 January 1823, which is the Feast Day of the Three Holy Hierarchs, ${ }^{23}$ the icon was discovered. A miraculous healing of one of the excavators' sons through the application of the dirt covering the icon verified the authenticity of the relic. The town council decided to build a church for housing the icon. Construction on the church lasted for over two years, until the church was able to receive visitors in $1825,{ }^{24}$ the final construction of the church, its façade, was completed in 1880.

Figure 11. The Holy Icon of Panagia Megalochari; (left) A Drawing of the Icon in 1858 by the Tinian painter Francisco Desipris; (right) My photograph of the Icon in 2018

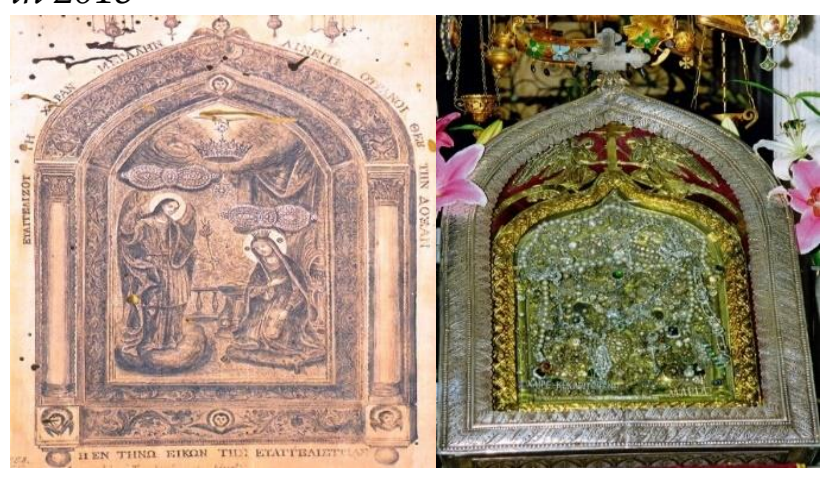

The icon depicts Panagia kneeling and accepting the future incarnation of Jesus while the archangel Gabriel extends a lily to her (Figure 11). The icon is so covered and overlaid with precious stones, gold, and other objects that it is impossible now to make out the scene's details. ${ }^{25}$ The icon has been claimed to be

23. Namely, Basil the Great, Gregory the Theologian, and John Chrysostom. For the origin of this Feast Day, see Ken Parry (ed.), The Blackwell Dictionary of Eastern Christianity (Oxford: Blackwell, 1999), 491-492.

24. The date is engraved in the chapel's wooden iconostasis.

25. Dubisch, "Golden Oranges and Silver Ships, 120; Håland, "The Dormition of the Virgin Mary, 94. 
the handiwork of the apostle Luke himself and thus mid-first century CE in date; it is even believed that Panagia, while still alive, approved of the work (Figure 12). Art historians and scholars, however, rightly assign the icon to the seventh century CE and argue that it was made for the Church of Saint John Prodromos, in whose debris the icon was found. When the Saracens destroyed the church in the tenth century, the icon was buried by the debris falling over it. ${ }^{26}$ The icon then remained underground, deep under the Tinian soil, for nine centuries.

\section{Figure 12. The Holy Icon in the Church of Panagia Megalochari}

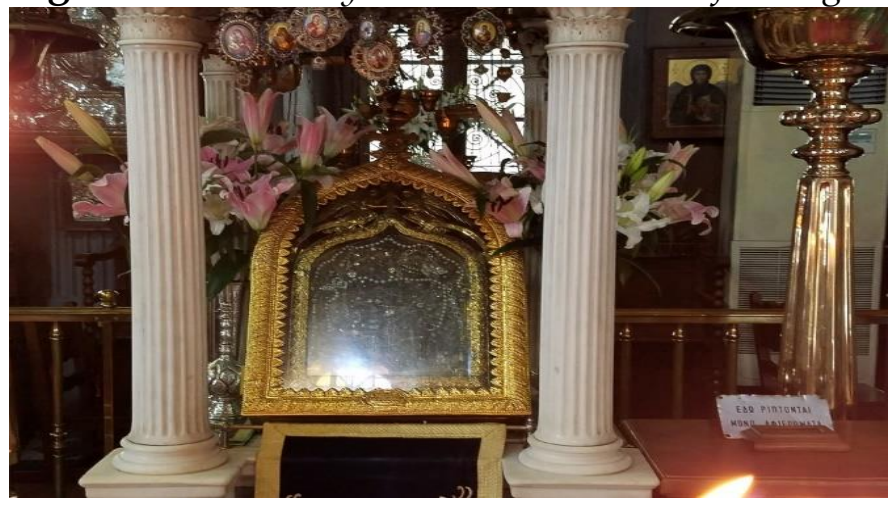

\section{Miracle Stories at Epidauros and Tinos}

The icon and/or Panagia Megalochari have performed numerous miracles as witnessed by the votive offerings but also letters and notes. Some of these documents accompanied gifts to the church, while others were sent afterwards to detail a fulfilled prayer or miracle. Many written documents have been preserved and are stored in the monastery's archives. I will quote some sample miracles from the authoritative texts of Tigkas ${ }^{27}$ and Amiralis. ${ }^{28}$

26. Dubisch, "Golden Oranges and Silver Ships, 121 with her note 10.

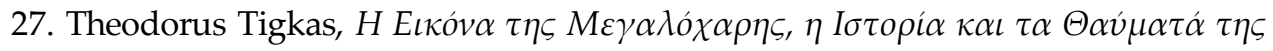

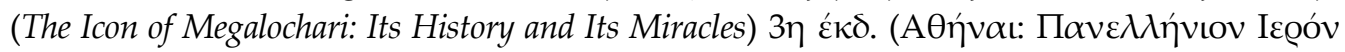

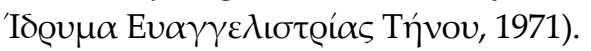

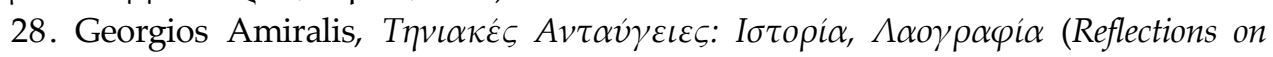

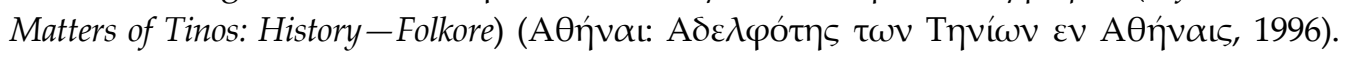
Also valuable and consulted here are Lagouros, especially pp. 69-75 for letters; Kornaros; Panhellenic Holy Foundation of Evangelistiria of Tinos; and Håland. [Alexandros

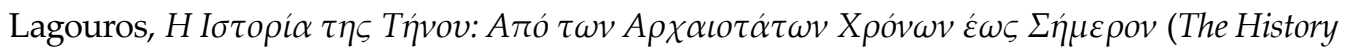
of Tinos: From the Most Ancient Times up to the Current Day) (AӨńvat: Tívos, 1965);

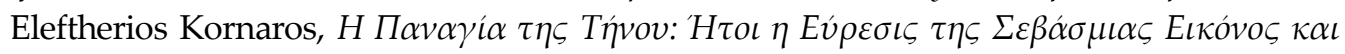

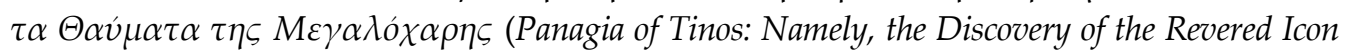

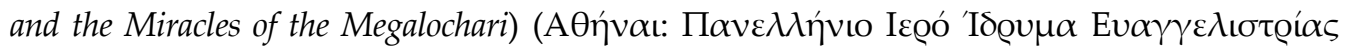

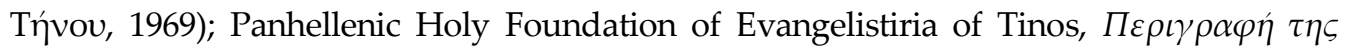

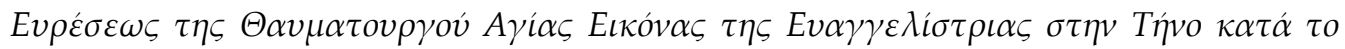

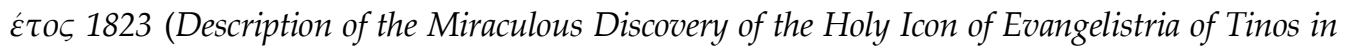


When one enters the sanctuary (from the door facing the entrance and the front courtyard), there is on the western (left) side a silver lamp. This was the gift of Spiros Merkouris (b. 1856-d. 1939), who served as mayor of Athens 1899-1914. In the archives is the following letter: ${ }^{29}$

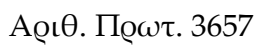

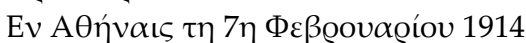

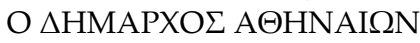

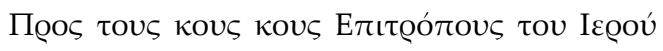

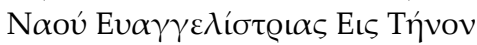

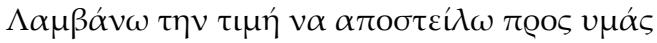
кц

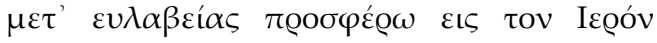

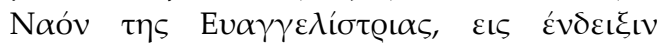

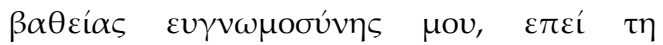

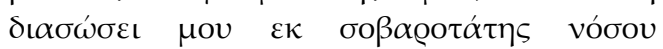

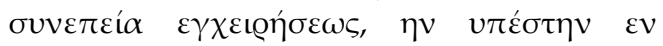

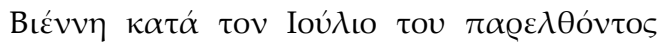
غ́ंous 1913.

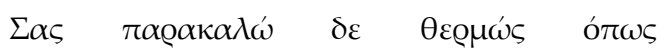

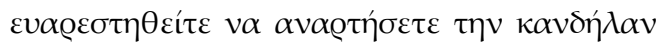

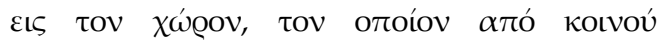

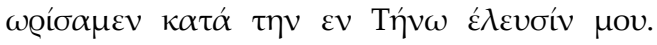

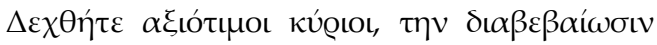

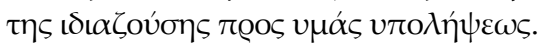

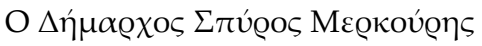

Reference Number 3657

Athens, 7 February 1914

THE MAYOR OF ATHENS

To the Commissioners of the Holy Church of Evangelistria on Tinos:

I have the honor to send to you a box containing a lamp, which out of piety I offer to the Holy Church of Evangelistria as a sign of my profound gratitude for having been saved from a most serious disease due to an operation that I underwent in Vienna in July of the previous year, 1913.

I earnestly ask you to be so kind as to hang the lamp in the place that we had mutually agreed upon during my visit to Tinos. Be assured, honorable gentlemen, of my special regards towards you.

Spiros Merkouris, Mayor

The occasion for the lamp gift was a vision of Panagia which Merkouris had after he had become afflicted with a possible pulmonary embolism following surgery in Vienna. Merkouris was in a potentially life-threatening situation. One night, while bedridden and in agony, he was visited by Panagia. He writes as follows:

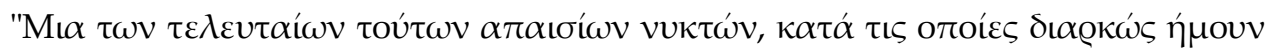

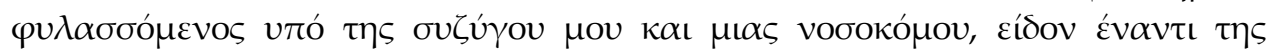

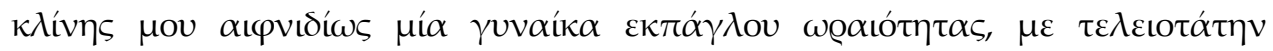

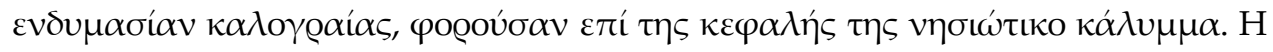

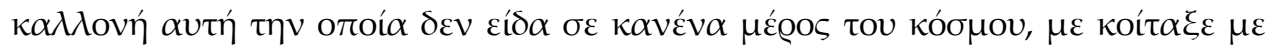
v́

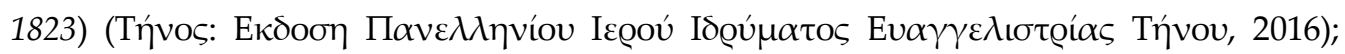
Håland, "The Dormition of the Virgin Mary, 123-136]. I was fortunate to have visited the sanctuary and archives in March of 2018; my thanks of gratitude to the staff of the Foundation for their hospitality and very kind reception and assistance.

29. Translations of this and other Tinos documents are mine. 


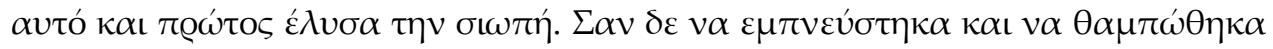

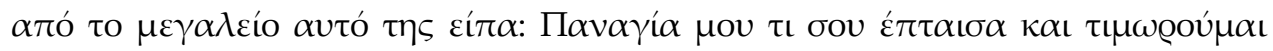

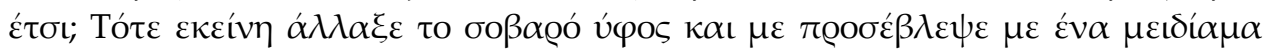

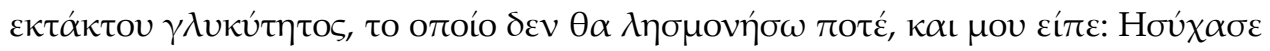

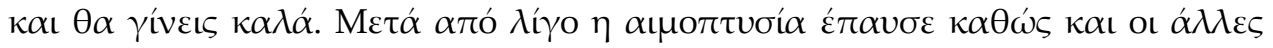

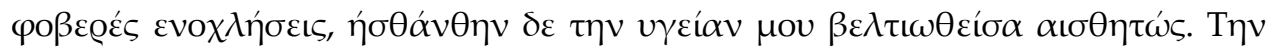

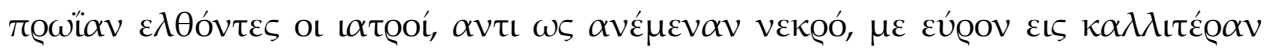

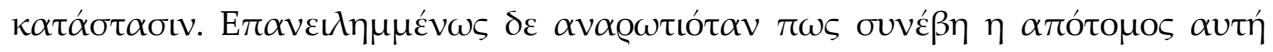

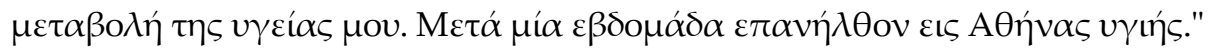
"On one of these recent dreadful nights, during which I was being watched over

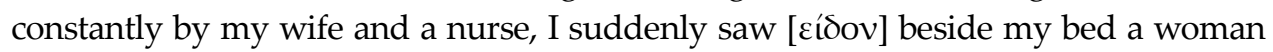
of extraordinary beauty with the most consummate attire of a nun, wearing an islander's head covering. This beauty, such as I have never before seen in any part of the world, scrutinized me in a serious and menacing mien as if she were cross with me. I was stunned at this. I was the first to break the silence. As though inspired and dazed by the very grandeur of this woman, I said: "My Lady, in what way have I offended you and why am I being punished?" She then changed her grave expression and looked upon me with such a smile of extraordinary sweetness that I will never forget it. She said to me: "Rest and you will be well." After a short time the hemoptysis stopped, as did the other horrible afflictions. I rested and my health noticeably improved. First thing in the morning the doctors came. They expected to find me dead, but instead they discovered that I was in a much better condition. They kept on asking me how such an abrupt change in my health had happened. After seven days I returned to Athens in good health."

What Merkouris experienced was an epiphany of Panagia, an epiphany of the same sort that suppliants at Epidauros had of Asklepios. The language is the same: cídov looks back to the dream accounts of dreams and visions received by the ill at Epidauros. ${ }^{30}$ The text of Merkouris's letter clearly implies that he had a waking vision. In Eastern Christian hagiography, there were a number of words for describing a vision: ó@ $\alpha \sigma \iota \varsigma$, ó@ $\alpha \mu \alpha$, and ö $\psi \iota \varsigma$ (all synonyms for "vision"). If the vision occurred during sleep, a qualifying phrase was often added, e.g., $\kappa \alpha \theta^{\prime}$ útvous ("during sleep"), or the circumstances surrounding the event was highlighted, e.g., коца́о $\mu \alpha$ เ ("while I was lying in bed"). ${ }^{31}$ In Merkouris's

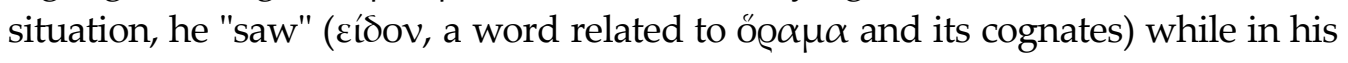
bed and awake.

Merkouris's dream vision is remarkably like those experienced by the second-century CE writer, Aelius Aristides, who was a fervent follower of

30. Merkouris uses the classical form of "I saw," rather than the modern $\varepsilon$ í $\delta \alpha$. The records of Asklepian dream visions nearly always uses eĩoov.

31. Oberhelman, "Interpretations of Signs and Dreams: Greek Christian Traditions," in Prophecy and Prognostication in Medieval European and Mediterranean Societies, ed. Matthias Heiduk (Berlin: Walter de Gruyter, forthcoming). 
Asklepios. ${ }^{32}$ Aristides preserved in his Hieroi Logoi (The Sacred Tales) the 130 dreams that he received between 130 and $171 \mathrm{CE}$; his dreams, with embedded epiphanies of Asklepios and other gods, are a record of this man's religious and medical journey.33

In Book 2 of Hieroi Logoi, Aristides recounts an epiphany of the goddess Athena when he was lying in bed one night. ${ }^{34}$ He writes (chap. 41):

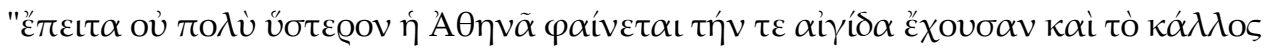

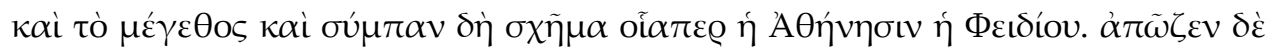

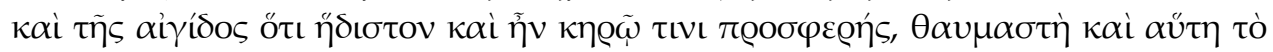

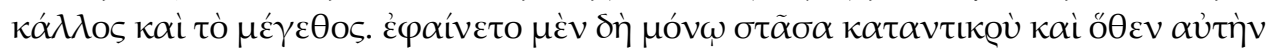

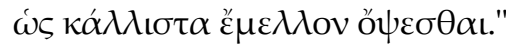

"Then not much later, Athena appeared with her aegis and the beauty and magnitude and the whole form of the Athena of Phidias in Athens. There was also a scent from the aegis as sweet as could be, and it was like wax, and it too was marvelous in beauty and magnitude. She appeared to me alone, standing before me, even from where I would behold her as well as possible."

Aristides continues to narrate how Athena reassured him of her help despite his being on his death bed. As it turns out, Aristides interpreted Athena's appearance metaphorically as a sign that he should be given by an enema of Attic honey, which did end up purging him of his bile. ${ }^{35}$ Merrkouris did not receive a directive for an enema or such prophylactic measures; rather, he was cured simply by the power and grace of Panagia. But both Aristides and Merkouris describe an epiphany of a wondrous and beautiful woman who visited them while lying deathly ill and who provides a miraculous cure.

32. Ido Israelowich, Society, Medicine and Religion in the Sacred Tales of Aelius Aristides. Mnemosyne. Supplement volume, 341 (Leiden: Brill, 2012); Ursula Bittrich, TraumMantik-Allegorie: Die Hieroi Logoi des Aelius Aristides im weiteren Kontext der griechischrömischen Traumliteratur (Dream Manty Allegory: The Hieroi Logoi of Aelius Aristides in the broader context of Greco-Roman dream literature) (Berlin \& Boston: Walter de Gruyter, 2017).

33. Aldo Tagliabue, "An Embodied Reading of Epiphanies in Aelius Aristides' Sacred Tales," Ramus 45 (2016): 213-230.

34. In Book 2, chaps. 40-43; text from Kouki; translation from Behr. [Elisabeth Kouki,

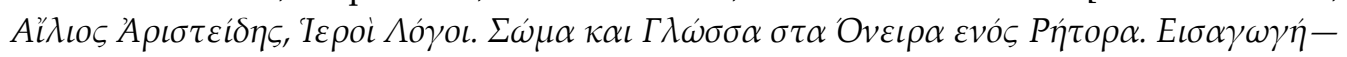

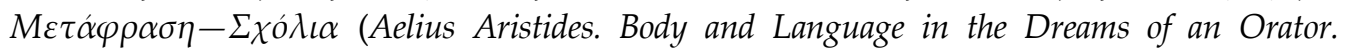

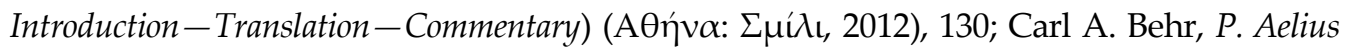
Aristides, The Complete Works; Volume II: Orations XVII-LIII (Leiden: Brill, 1981), 299-300].

35. For such narratives and metaphorical interpretations of dreams in Aristides Hieroi Logoi, see Janet Downie, At the Limits of Art: A Literary Study of Aelius Aristides' Hieroi Logoi (New York: Oxford University Press, 2013); Downie, "Narrative and Divination: Artemidorus and Aelius Aristides," Archiv für Religionsgeschichte 15 (2015): 97-116; Lee T. Pearcy, "Theme, Dream, and Narrative: Reading the Sacred Tales of Aelius Aristides," Transactions of the American Philological Association 118 (1988): 377-391. 
Another epiphany of Panagia was recorded in 1972 by Markos Siotis, who was elected in 1993 to the Academy of Sciences of Athens and was professor emeritus of the New Testament of the School of Theology of the University of Athens. ${ }^{36} \mathrm{He}$ mentions a series of miraculous events that he himself witnessed. Siotis was in the Church of Panagia Megalochari during the all-night vigil that takes place annually on the night of 14 August, right before the 15 August Assumption Day activities on Tinos. ${ }^{37}$ At first light of 15 August, the sanctuary was suddenly filled with cries of the suppliants who saw Panagia above them. At that very moment, Siotis writes that three miracles happened through

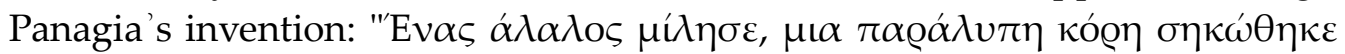

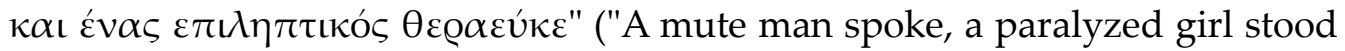
up, and an epileptic man was cured"). The three miracles are a direct parallel to three famous miracles performed by Jesus, as recorded in the gospels. ${ }^{38}$

The suppliants' interactions of suppliants with Asklepios at the Epidaurian sanctuary are documented in extant inscriptions. Four stelai, surviving from the fourth century CE, preserve 70 stories of people who were healed or helped at the sanctuary (Figure 13). ${ }^{39}$ The stelai, which are housed in the museum at the site, were part of the six that ancient authors describe. ${ }^{40}$ The stories on the stelai were collected from oral traditions, priestly traditions from stories that they were told, or deduced from the depictions on votive plaques. ${ }^{41}$ The vast majority of the

36. A year earlier, in 1971, Panagia appeared to two pilgrim women who were wandering lost in the dark. Panagia gave them directions to the house where they were staying; the house turned out to be the one formerly owned by Stamatelos Kangadis, who headed up the excavations in 1822-1823 and who first held the icon when it emerged from the soil.

37. The all-night vigil and the holy days are especially conducive to Panagia performing miracles: Dubisch, "Men's Time and Women's Time, 8; Håland, "The Dormition of the Virgin Mary, 99.

38. See Mark 7:31-37, 2:1-12, 9:14-16, respectively. The only difference is that Jesus healed a paralyzed man, not a paralyzed girl. Siotis calls Panagia's appearance a $\pi \alpha \varrho 0 v \sigma i ́ \alpha$, a term that described in ecclesiastical and secular texts the arrival of kings and other royal personages.

39. Asklepios did not just heal but offered advice on current and future events and problems; Ploeg divides the stories on the stelai into medical and divinatory; see the discussion in chapter 2. [Ghislaine van D. Ploeg, The Impact of the Roman Empire on the Cult of Asclepius (Oxford: Oxford University Press, 2019)].

40. LiDonnici, Tale and Dream; and LiDonnici, The Epidaurian Miracle Inscriptions, for text and English translation; LiDonnici ["Compositional Background of the Epidaurian 'Iamata'," The American Journal of Philology 113 (1992): 25-41] for compositional techniques; Gerhard Pfohl [Inschriften der Griechen. Epigraphische Quellen zur Geschichte der Antiken Medizin (Inscriptions of the Greeks. Epigraphic sources on the history of ancient medicine) (Darmstadt: Wissenschaftliche Buchgesellschaft Darmstadt, 1977)] for the overall inscriptional evidence. Also Renberg, Where Dreams May Come, vol. I: 171-178.

41. LiDonnici, The Epidaurian Miracle Inscriptions, 40-46. 
stories focus on healing, but we read about miracles connected to pregnancies, hopes of becoming pregnant, finding a missing person or object, and concerns over business ventures and sailing trips.

Some suppliants received a vision while asleep, as noted by the phrase

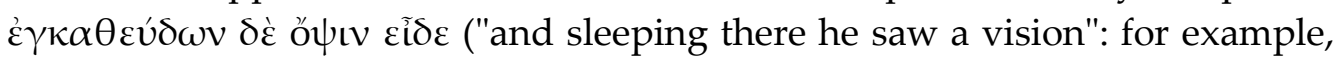
Stele A, line 25). ${ }^{42}$ This phrase, very common in the stele inscriptions, shows that this is an epiphany-vision which occurs while the suppliant is lying down in the abaton. ${ }^{43}$ Other suppliants were cured during the course of the night, with the god's actions recalled in the person's dream. So, for example, "Once a man came as a suppliant to the god who was so blind in one eye that, while he still had the eyelids of that eye, there was nothing within them and they were completely empty... Then in his sleep, a vision appeared to him. It seemed that that the god boiled some drug, and then drew apart his eyelids and poured it in. When day came he departed with both eyes" (Stele A, lines 7278). ${ }^{44}$ And, "Timon, wounded by a spear below his eye. This man, sleeping here, saw a dream. It seemed to him the god ground up an herb and poured it into his eye, and he became well" (Stele B, lines 119-122). ${ }^{45}$

Figure 13. Stele A, Containing Asklepian Miracle Cures, Epidauros Museum

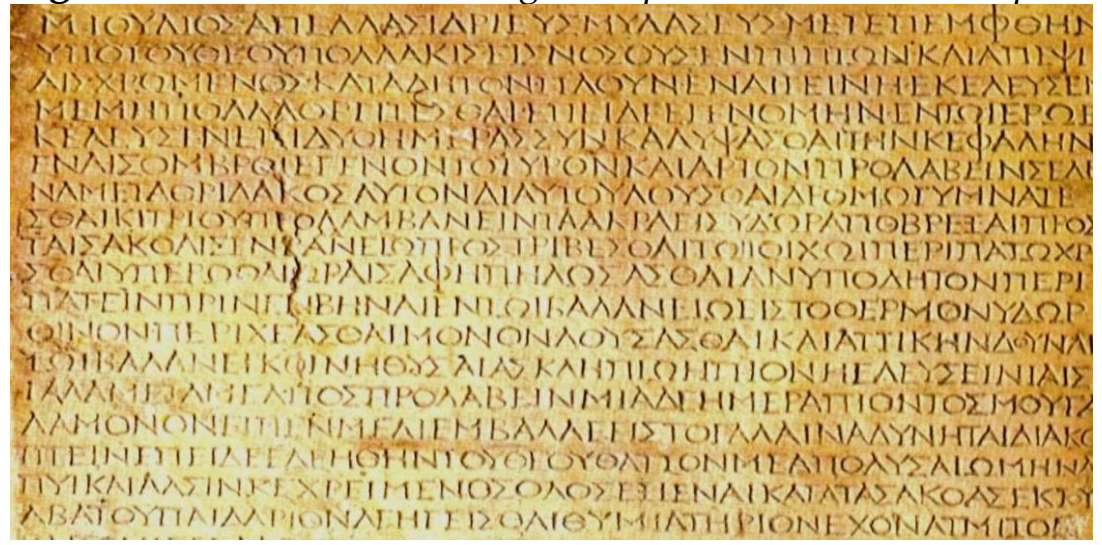

For other suppliants the god simply intervened miraculously. The suppliant had no memory of any dream, vision, or nighttime action-we read only of a

42. Ibid., 86 .

43. Suppliants did not necessarily need to be sleeping to receive a vision or to be cured. Very little skepticism was expressed in antiquity about the miracles of the Askepian sanctuaries; they were accepted on face value. Even Aristophanes' comedy Plutus centers not on the miracle of the god Plutus (Wealth) being given his eyesight at the temple of Asklepios (accepted as real), but on how Plutus begins to hand out riches to the deserving and to remove riches from the undeserving, thereby reversing the inequitable distribution of wealth; see Konstan and Dillon for analysis. [David Konstan and Matthew Dillon, "The Ideology of Aristophanes' Wealth," The American Journal of Philology 102 (1981): 371-394].

44. LiDonnici, The Epidaurian Miracle Inscriptions, 93.

45. Ibid., 115. 
cure occurring during sleep. Thus, "Heraieos of Mytilene. This man had no hair on this head, but plenty on his chin. Ashamed because he was laughed at by others, he slept there. The god anointed his head with a drug and made it have hair" (Stele A, lines 122-125). ${ }^{46}$ And, "Aischenes, when the suppliants were already sleeping, went up a tree and peered over into the Abaton. Then he fell out of the tree and impaled his eyes on some fencing. In a dreadful state, having been blinded, he earnestly prayed to the god, slept there, and became well" (Stele A, lines 90-94). ${ }^{47}$

\section{Parallels and Differences between Epidauros and Tinos}

An important difference between the healing miracles at Epidauros and the miracles of Panagia at Tinos is that Asklepios cured through touch, application of medicines, or surgery, or he communicated in a dream vision the appropriate curative measures that the suppliant should undertake after awakening. Panagia simply cures either through her own agency or by bringing prayers to her son Jesus.

Another difference is that although Asklepios never charged a fee for his services and was not discriminatory in whom he healed, a suppliant was expected to make sacrifices and undergo ritual purifications, as well as to offer a final thanks gift. ${ }^{48}$ At Tinos there is no preliminary rite, and tamata are not offered unless the suppliant wishes to do this. Most suppliants bring tamata, but they are simply expressions of gratitude for answered prayers.

Also, suppliants come to Tinos already cured, not seeking a cure. While a few miracles, as we have seen above, may occur in the Church of Panagia Megalochari, the miracle takes place in the suppliant's home or village. Miracles are connected indirectly to the church: People come to the church to worship the icon, give offerings to Panagia, fulfill a vow, or thank Panagia for the miracle that had happened. The Epidaurian inscriptions position Asklepian cures as occurring in, and as connected to, the sanctuary. Except for the rare individual like Aelius Aristides who seemed to have received dreams from the god in various locales, people went to the god, whether in public or private cult worship places, for a miraculous cure. ${ }^{49}$ Panagia, on the other hand, although connected to the icon and the sanctuary at Tinos, is everywhere and is approachable simply through prayer, and so a pilgrim's first visit to Tinos may actually be to bring her tamata in response to a prayer that she had answered in Thessaloniki or Kavala. Panagia,

46. Ibid., 99.

47. Ibid., 95.

48. Edelstein and Edelstein, Asclepius: A Collection and Interpretation of the Testimonies, vol. II, 186-190.

49. Renberg, "Public and Private Places of Worship in the Cult of Asclepius at Rome," Memoirs of the American Academy in Rome 51/52 (2006/2007): 87-172. 
in other words, is a spiritual experience and is not specifically tied to a locale. ${ }^{50}$

There are similarities, however, between Asklepios and Panagia. First, both can help when doctors cannot. At Epidauros, the god displayed his power in curing when doctors saw no hope or when he overruled the suppliant's medical treatment. The latter happened to Eratokles of Troezen, who was "suffering from pus. When he was sleeping in the sanctuary in Troezen, waiting to be cauterized by the doctors, the god came to him, and ordered him not to have cauterization, but to sleep in the sanctuary of the Epidaurians. When the time had passed, which had been commanded, the pus burst forth, and he left well" (Stele C, lines 28-33). ${ }^{51}$

Tigkas ${ }^{52}$ records two miracles when Panagia offered help beyond what secular medicine could provide. A Panagiota Nazou was suffering from an incurable wound that had become gangrenous. Doctors were ready to amputate her leg, but the young girl prayed to Panagia who then miraculously healed her leg. A Konstantinos Traiforos, a ship's captain from Spetses, had become blind and deaf due to a dizzy spell (possibly a stroke). He was told to start formal medical treatments but he insisted on being taken to the Church of Panagia Megalochari. There, after 40 days of prayer, he washed his eyes and ears with holy water and became well.

Both Asklepios and Panagia have a specialization in pregnancy and sterility issues. Women came to Epidauros to seek pregnancy after years of sterility or to secure help with difficult pregnancies. The very first two miracle cures on the Epidaurian stelai deal with lengthy pregnancies: five years (Kleo: Stele A, lines 19) ${ }^{53}$ and three years (Ithmonika of Pellene: Stele A, lines 9-22). ${ }^{54}$ Women also came to the sanctuary to become pregnant. Andromache from Epirus, "when she was sleeping, saw a dream. It seemed to her that a handsome young boy uncovered her, and after that the god touched her with his hand. From this a son was born..." (Stele B, lines 60-63)..$^{55}$ An unnamed woman from Troezen came because she was childless. While sleeping in the abaton, she "saw a dream, It seemed to her that the god said that she would have a family and he asked whether her wish was for a male or a female, and she said she wished for a male. After this, within a year a son was born to her" (Stele B, lines 82-85). ${ }^{56} \mathrm{~A}$ miracle was performed by Panagia for a woman from Evia. This unnamed woman had no child after 10

50. Most monasteries and villages, Greek and even non-Greek (like Syria, Israel, and

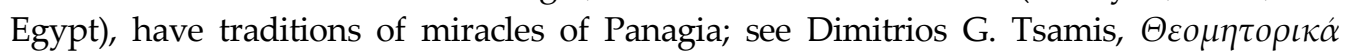

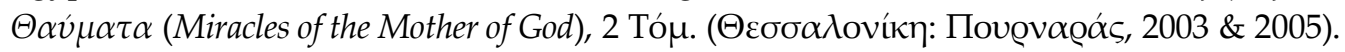

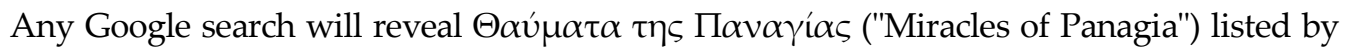
location and year.

51. LiDonnici, The Epidaurian Miracle Inscriptions, 123.

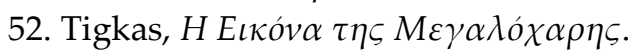

53. LiDonnici, The Epidaurian Miracle Inscriptions, 85.

54. Ibid., 87.

55. Ibid., 109.

56. Ibid., 111. 
years of marriage, for which her husband threatened divorce. On the advice of her mother-in-law the two women went to pray at the Church of Panagia Megalochari. By happenstance, when they arrived and began to pray, the church was celebrating the anniversary mass for the discovery of the holy icon (30 January). After the mass, the woman asked for a piece of the lamp wick burning in front of the holy icon. The woman swallowed it with holy water, and within a year she gave birth to a male child. Other women take less extreme measures. As noted above, the icon is taken from the church on 15 August, the Feast of the Assumption of the Virgin. When it is paraded down Leôforos Megalocharês, women lay down in the street so that the icon will be passed over them; this, it is claimed, will result in pregnancy. ${ }^{57}$

Askelpios and Panagia can effect miraculous cures through material things. The objects themselves do not possess curative power; they are only the means through which the god or Panagia accomplish the miracle. Asklepios typically used animals, such as dogs (Stele A, lines 125-126, \& Stele B, lines 35-38), ${ }^{58}$ snakes (Stele A, lines 113-139), ${ }^{59}$ and even geese (Stele B, lines 132-133). ${ }^{60}$ As for Panagia, the very first miracle associated with the holy icon happened right after its discovery. The excavators found an unknown substance covering the icon's surface; the substance was glassy-like and very smooth, although some thought it was just earth and water. The son of Georgios Peridis, one of the excavators, was afflicted with the plague and was suffering from high fever and swellings under his armpits. Peridis prayed and then took some of the icon's surface scum and mixed it with holy water; he then spread this mixture with cotton on the child's armpits. The very next day the child was cured.

Holy water $\left(\alpha \gamma^{\prime} \alpha \sigma \mu \alpha\right)$, taken from the well in the Church of Zoôdochos Pigi beneath the Church of Panagia Megalochari, is responsible for many miracles. ${ }^{61} \mathrm{~A}$ captain named Sclavounos suffered from a fishbone stuck in his throat for two years, and the bone could not be expelled. The result was that the captain was afflicted with constant pain and infections. The doctors could not help and told him that he would eventually die. When the captain heard about the icon of Panagia, he went to pray for a cure. As he drank holy water and was washing his face, he violently coughed and expelled the fishbone. Likewise, a man from Tarabados, suffering from dropsy, was taken by his wife to the Church of Panagia Megalochari; after prayers he went down to the well of Zoôdochos Pigi and drank some of the water and washed his face with it. Suddenly, water gushed

57. Dubisch, "Men's Time and Women's Time, 4; Håland, "The Dormition of the Virgin Mary, 99-100.

58. LiDonnici, The Epidaurian Miracle Inscriptions, 99, 105.

59. Ibid., 97.

60. Ibid., 115.

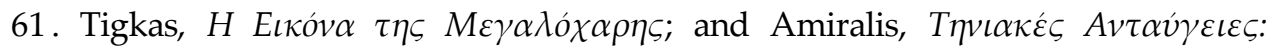

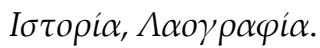


from all the pores of his body, causing the loss of so much fluid that he was restored to health. A final cure through holy water involved a marble sculptor named Nicolas from western Turkey; he was suffering from an eye injury caused by a piece of marble that had lodged in his eye. The doctors were unable to help, and so when Nicolas came to the icon he prayed. Afterwards he washed his eye with holy water; the fragment came out and his eyesight was fully restored.

One of the more unusual cures attributed to the icon itself involves sweat. A Gregory Athinaios had become blind. He came to the Church of Panagia Megalochari during a rogation for an insane woman. ${ }^{62}$ At the end of the intercessory prayers, the icon began to sweat. He collected the sweat and with a piece of cotton spread it on his eyes. His eyesight was immediately restored.

Another point of similarity between Asklepios and Panagia is that illness is not the only reason why they are petitioned. Lost items can be recovered; lost people can be found. At Epidauros several such miracles are recorded. A certain boy named Aristokritos from Halieis had been diving in the sea but had then been swept away by the waves. Although he survived by clinging to rocks, he was considered lost. His father came to Epidauros and slept in the abaton. That night he saw a dream in which Asklepios showed him the exact spot where the boy was to be found. Indeed a week later the boy was discovered in that very place (Stele B, lines 19-26). ${ }^{63}$ In another miracle a woman named Kallikrateia came to the god seeking information on how to find the gold that her dead husband had hidden somewhere. The god revealed the hiding spot (Stele C, lines 8-21). ${ }^{64}$ The first miracle story has a parallel to a miracle that Panagia performed in 1824, the year after the icon was excavated. A merchant of the town, Alivizos Kalavrias, dove into the sea, having become delirious from an illness. On the point of drowning, Alivizos prayed for rescue from Panagia. He felt a hand push him from underneath the waters. Somehow he stayed afloat the water for the night until he was spotted by a fisherman. The miracle not only was that he had not drowned (he did not know how to swim), but that no water was in his lungs and his original illness was cured too. Whether such miracles at Tinos and Epidauros happened exactly as reported, or are fictitious, or simply embellishments of actual events cannot be recovered. ${ }^{65}$

62. Rogation days are times that the church has established for petitions to God for protection; the Litany is sung in procession and every sort of prayer, usually intercessory or petitionary, is offered.

63. LiDonnici, The Epidaurian Miracle Inscriptions, 103.

64. Ibid., 119.

65. See Dillon, who is skeptical about Epidauros. [Matthew Dillon, "The Didactic Nature of the Epidaurian Iamata," Zeitschrift für Papyrologie und Epigraphik 101 (1994): 257]. 


\section{The Written Stories and Their Purpose}

The Epidaurian inscriptions and the stories associated with the holy icon and Panagia serve ideological, political, and religious purposes. The stories were originally private and personal, but they became public documents that reflected, reinforced, and perpetuated the public perception and ideology of the sanctuaries, whether Epidaurian and fourth century BCE or Tinian (even Panhellenic) and of the modern period. ${ }^{66}$ Despite the original source of the Epidaurian stories (the information written on votive plaques, pictorial depictions on votive-reliefs and then reshaped by priestly traditions, or oral and/or written documents, ${ }^{67}$ the stories on the stelai were assembled and published with the purpose of being viewed, of being read, and of being proof of what the god could and would do. The ultimate aim of the stories was to dispel any doubts of the efficacy and truthfulness of the god and his power to heal, to restore, and to help. The stelai constituted a public discourse that reinforced the belief-systems of the suppliants visiting the sanctuary. ${ }^{68}$

Evy Johanne Håland ${ }^{69}$ has nicely demonstrated the ideological aspects of the three major festivals on Tinos and as celebrated at the sanctuary of Panagia Megalochari. Jill Dubisch likewise, in a series of articles ${ }^{70}$ has tied the shrine to the birth and survival of the modern Greek state. ${ }^{71}$ But, thanks to the Internet and the easy availability of online and printed materials, the miracles of Panagia at Tinos are no longer the private reserve of the monastery's archives

66. LiDonnici, The Epidaurian Miracle Inscriptions, 2-3; Håland, "The Dormition of the Virgin Mary; and Håland, Greek Festivals, Modern and Ancient, chap. 4.

67. LiDonnici, Tale and Dream, 238-247

68. For a bibliography on the similarity of the Epidaurian iamata inscriptions and Christian miracle story collections, see Renberg, Where Dreams May Come, vol. II: 781-782.

69. Håland, "From the Ritual Year of the Miraculous Icon on the Greek Island of Tinos to the Wider Mediterranean," Comparative Civilizations Review 63 (2010): 19-36; Håland, "The Ritual Year of the Icon of the Annunciation on the Island of Tinos, Greece," Folklore: Electronic Journal of Folklore 47 (2011): 91-112; Håland, "The Dormition of the Virgin Mary; Håland, Greek Festivals, Modern and Ancient.

70. Dubisch, "Golden Oranges and Silver Ships; Dubisch, "Men's Time and Women's Time.

71. See especially Dubisch, "Golden Oranges and Silver Ships, 121-128; and Dubisch, "Men's Time and Women's Time, 8-9; cf. Håland, "The Dormition of the Virgin Mary, 105. The integration of nationalism and religion is evidenced by the positioning of the Mausoleum of the Elli. The Mausoleum, devoted to the victims of the torpedo attack on the cruiser Elli by the Italians on 15 August 1940, is under the church itself and right next to the Church of Zôodochos Pigi. The Elli was in port as part of the Feast of the Assumption but was hit by three torpedoes. Today, on the eve of 15 August, warships of the Hellenic fleet anchor in the harbor. A wreath is laid by the Chief of the Fleet at the Mausoleum of Elli. Representatives of the Greek government, political dignitaries, and religious leaders participate in the festivities. 
but are disseminated across Greece. Pilgrims now come to Tinos primed for miracles through a belief-system that has been reinforced by public distribution of private stories of salvation and restoration of health by Panagia. The stories serve as a reinforcement of the tamata that hang from the church's ceiling and are spread around the interior of the sanctuary, and as a verification of the faith displayed by the people crawling up the Leofforos Megalocharis on hands and knees, by the shopkeepers selling small bottles for holy water and tamata to present at the sanctuary, and by elderly women offering one-euro statues in the park before the sanctuary's entrance. ${ }^{72}$ Even the voyage (two to four hours depending on whether one uses a sea jet or a ferry) puts one into a mood of anticipatory excitement. Whereas previously the beautifully crafted orange tree in the Church of Panagia Megalochari instilled awe in the onlooker, stories published on the Internet tell a fuller, richer, and more compelling picture of the miracle that produced the tamata orange tree. Numerous websites describe how the American Georgios Lambrakis, afflicted with blindness and having heard of the miracles of Panagia Megalochari, came to the church and

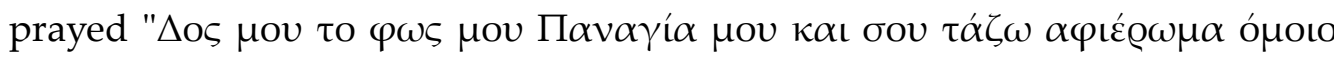

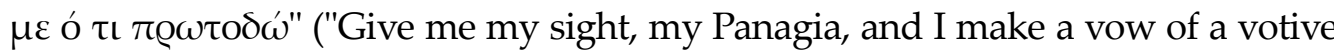
offering identical to whatever I see first"). ${ }^{73}$ Lambrakis later received his sight. When he opened his eyes for the first time, he saw an orange tree in his gardenhence, the orange tree votive offering (Figure 14). ${ }^{74}$ The orange tree in itself is a powerful testimony as an object, but its story is more powerful: what is seen is strengthened by what is read. In an age of widespread literacy objects have voices.

Another example of votives acquiring greater significance through the written text is the marble fountain positioned to the right of the staircase leading up to the Church of Panagia Megalochari (Figure 15, left). This fountain was the gift of Kiutahiji Mustafa Aga, a Turkish military commander on Crete who was healed in $1845 .{ }^{75} \mathrm{~A}$ Greek doctor brought Mustafa Aga to the sanctuary, where Panagia healed the commander during the liturgy. In gratitude, Mustafa Aga had a fountain constructed and then placed it in a place where all visitors to the sanctuary could see it. The fountain was a very visible reminder of the miraculous power of Panagia, but no story framed it, except as a priest or official or suppliant knew of the tradition. But now, thanks to the many free pamphlets, articles by laypeople and scholars, and Internet websites, the story is widely and easily known. Panagia's miracle was attributed to her only in a short dedicatory

72. Dubisch, "Men's Time and Women's Time, 2-3.

73. The personal nature of this episode is stressed by the thrice-repeated $\mu$ ov (both "my" and "me") in the first seven words.

74. Since the cure was not immediate, the story serves a subordinate purpose in stressing the sometimes delayed nature in how Panagia answers prayers.

75. Dubisch, "Golden Oranges and Silver Ships, 125. 
inscription at the base of the fountain (Figure 15, right), but it lacked context, a story. Most pilgrims probably simply glanced at the fountain as they walked up the stairs to the main church. But now that the story is advertised in written materials, pilgrims head to it to admire the workmanship and the miracle that inspired it.

Figure 14. The Orange Tree Votive Offering of Georgios Lambrakis, Church of Panagia Megalochari

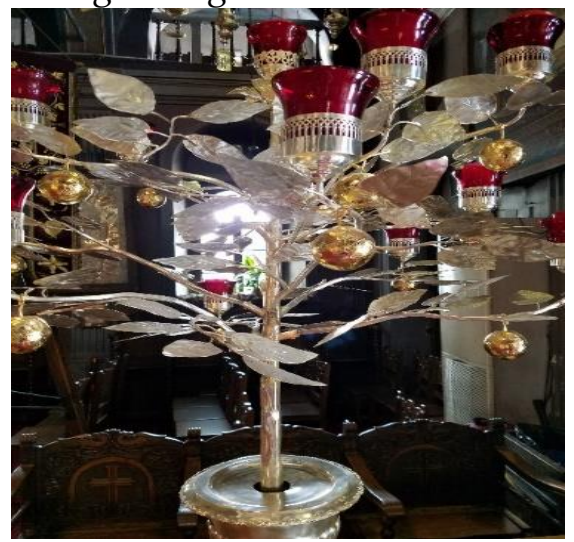

Figure 15. The Fountain Offering of Mustafa Aga, Dated to 1845: Fountain (left) and Dedicatory Inscription (right), ${ }^{76}$ Sanctuary of Panagia Megalochari

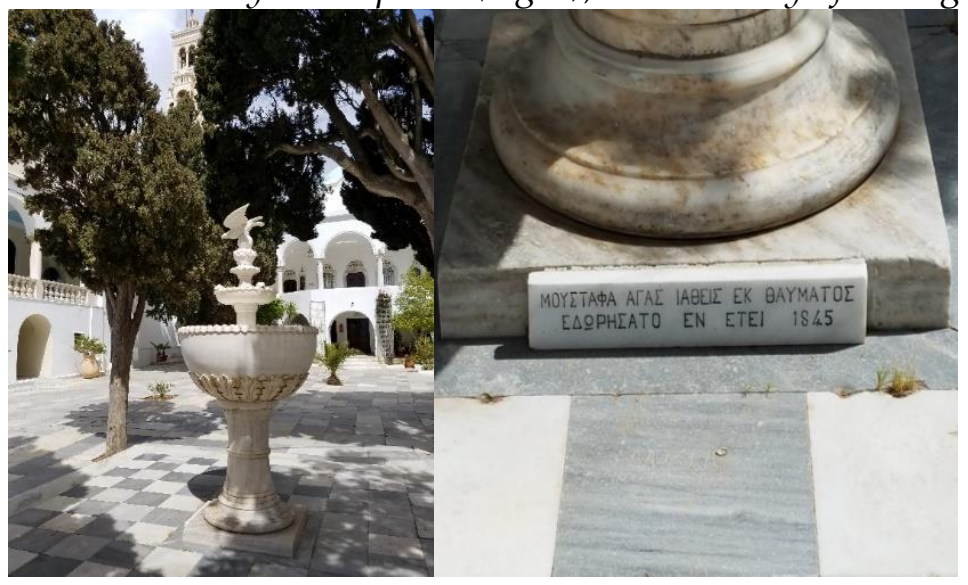

In a similar way the early votive-gifts at Epidauros were pictorial stories depicted in stone, terracotta, and wood. But it was the stelai that gave written stories to the images, texts that give further confidence to the faithful and rebuke the skeptic. ${ }^{77}$ Two of the first four stories on the stelai testify to the god's power

76. The inscription is translated as "Mustafa Agas, healed by a miracle, presented this as a gift in the year 1845."

77. Dillon, "The Didactic Nature of the Epidaurian Iamata, 242-243, 251. 
and to the futility of disbelief. In lines $22-32$ of Stele $A,{ }^{78}$ a man who scoffed at the

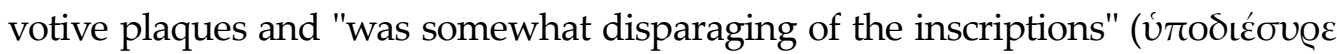
$\tau \dot{\alpha} \dot{\varepsilon} \pi \imath(\rho \alpha \mu \mu \alpha \tau \alpha)$ is convinced of the truth of Asklepios's healing ability after being cured during his sleep. Because of his lack of faith, the man was given a new name by the god:

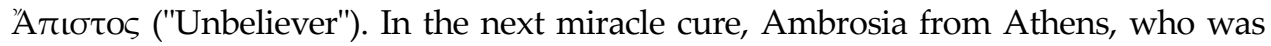
blind in an eye, came to the sanctuary (Stele A, lines 33-41). ${ }^{79}$ While walking around she looked around at the votives and "ridiculed some of the cures as being unlikely and impossible, the lame and blind becoming well from only seeing a dream" ( $\tau \tilde{\omega} v$

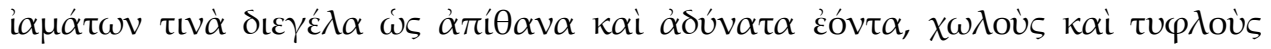

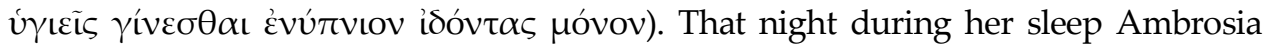
saw a dream in which Asklepios cut open her eye and poured a medicine into it, thereby curing her. Ambrosia was also told by the god to dedicate a "silver pig" ( $\tilde{v} \mathrm{v}$

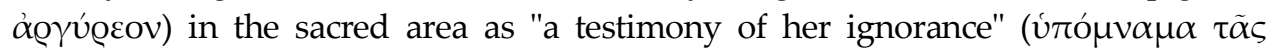
$\dot{\alpha} \mu \alpha \theta i \alpha \varsigma)$ both for herself and (this is the point of the story) for any doubter visiting the sanctuary after her. The silver pig, displayed for public view, was simply a votivesuppliants walking by and seeing it may have even wondered whether the god had healed someone's pig. But the stele offered a compelling story, a story of unfounded doubt and of a god's ability to perform miracles. For Ambrosia's fellow Athenians visiting the sanctuary, ${ }^{80}$ the stele and the pig, not merely the silver pig, became testimony of a faulty belief-system that had been turned into faith. As Matthew Dillon ${ }^{81}$ has stated, "The iamata [the stelai inscriptions] are aretalogiai, ${ }^{82}$ records of cures attesting to the arête [excellence] and dynamis [power] of the god."

\section{Conclusion}

Jill Dubisch ${ }^{83}$ has written that each generation, every new set of pilgrims, rereads the "text" of the sanctuary on Tinos. The offerings, the rituals, the visions, and the miracles are given new interpretations, building on and amplifying the previous "reading" of the sanctuary. The sanctuary itself was built upon the old and emerged from the old: It was erected over what was a pagan temple and was constructed from marble purloined from the pagan ruins of the island of Delos over the remains of an early Byzantine basilica. ${ }^{84}$ The present-day church is the

78. LiDonnici, The Epidaurian Miracle Inscriptions, 87.

79. Ibid., 89.

80. Most Athenians were able to read in the fourth century BCE. [F. David Harvey, "Literacy in the Athenian Democracy," Revue des Études Grecques 79 (1966): 585-635].

81. Dillon, "The Didactic Nature of the Epidaurian Iamata".

82. These are narratives that recite a deity's qualities or virtues in working miracles. [Howard C. Kee, "Aretalogy and Gospel," Journal of Biblical Literature 92 (1973): 402-422].

83. Dubisch, "Golden Oranges and Silver Ships, 119.

84. Ibid., 123; and Dubisch, "Men's Time and Women's Time, 6. 
latest in a series of religious constructs and constructions in the same space for faithful across two millennia.

Each day pilgrims, concerned and oppressed by difficult circumstances, come to Panagia to make a tama (vow) or, filled with gratitude, to dedicate their tamata (votive offering). The pilgrims, mostly women,, 85 have the same abiding faith in the power of Panagia and her icon as the pilgrims of the past 150 years have possessed; but now they view and re-view the tamata in the sanctuary and the entire complex through a lens of written words. The texts are ubiquitous: the street leading up to the sanctuary sell pamphlets containing stories of visions and miracles, while the sanctuary's administrative office dispense their own free copies. In Greece of 1800 the literacy rate for men was 9\%, while women were nearly universally illiterate. ${ }^{86}$ Texts were useless in such an environment. But in today's Greece, which boasts a literacy rate of $97 \%$, pilgrims to Tinos read the written word and read the tamata through the framing of the word. Jesus, in the Gospel of John 20: 29, spoke these words to Thomas, who doubted the validity of the resurrection: "Because you have seen me, you have believed; blessed are those who have not seen and yet have believed." At Tinos, and at Epidauros, blessed the pilgrims who saw the votives and believed; but even more blessed the pilgrims who saw and read and believed.

\section{Postscript}

An excellent example of how tamata may be reinvented and re-imagined was the recent exhibit at the Byzantine and Christian Museum in Athens, Greece. The artist Kalliopi Lemos took an abandoned boat that had carried immigrants, and covered it with 10,000 tamata (Figure 16).

Figure 16. The Tamata Boat by the Artist Kalliopi Lemos

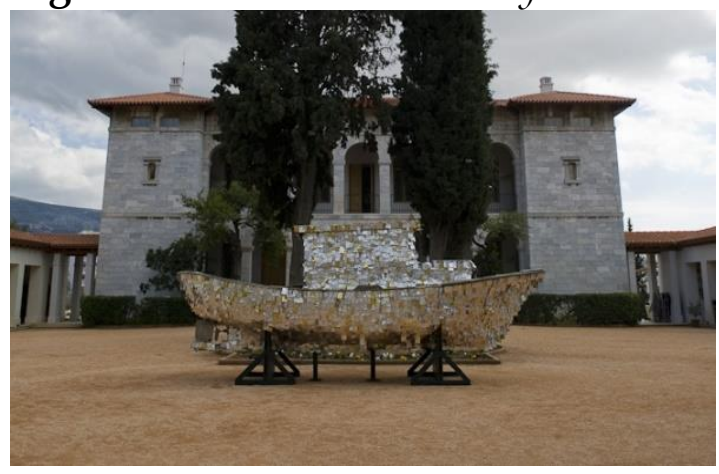

85. Dubisch, "Men's Time and Women's Time, 10-17.

86. Rebecca Rogers, "Learning to Be Good Girls and Women: Education, Training and Schools," in The Routledge History of Women in Europe since 1700, ed. Deborah Simonton (Abingdon and New York: Routledge, 2006), 103. 
The tamata were made from discarded beverage cans or were of the massproduced sort sold on Tinos (Figure 17). On each tama were inscribed the name, place, and date of birth of an immigrant who for various reasons fled their homeland. The exhibit, which I had the good fortune to see in May 2014, ran from 16 March through 30 September, 2014. The boat itself, located prominently in the open courtyard and visible to anyone walking along Leôforos Vasilissis Sofias, one of the busiest streets in Athens, was meant to serve as a symbol of the refugees' voyage from despair and death to life and hope. The tamata themselves had the purpose of initiating a dialogue about interculturality, equity, justice, and peace. As Lemos wrote in the notes to the exhibit, the immigrants' aspirations and life-stories, as encapsulated on the tamata, reflect the basic human desire for a better life.

Figure 17. Tamata on the Abandoned Boat

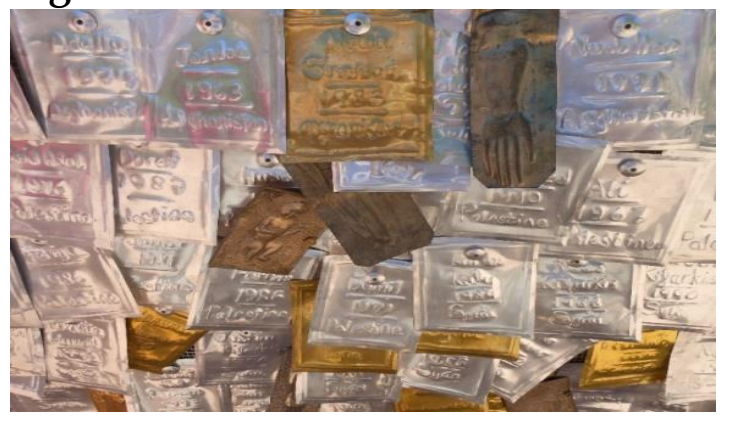

\section{Acknowledgements}

The first section of this paper ("Votive Gift Traditions in Ancient and Byzantine Greece") was presented as part of a fuller paper, "The Survival of Ancient Greek Votive Offerings in Byzantium and Modern Greece," Athens Institute for Education and Research, 5th Annual International Conference on Humanities \& Arts in a Global World, 3-6 January 2018. Further research and the remainder of the paper were completed while I was Visiting Senior Associate Member at the American School of Classical Studies in Athens in December 2017 and December 2018.

\section{Bibliography}

Aleshire, Sara B. The Athenian Asklepieion: Their People, Their Dedications, and Their Inventories. Amsterdam: J. C. Gieben, 1989.

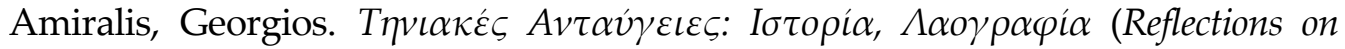

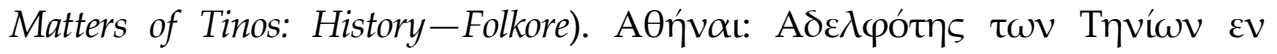
AӨற́vaıs, 1996. 


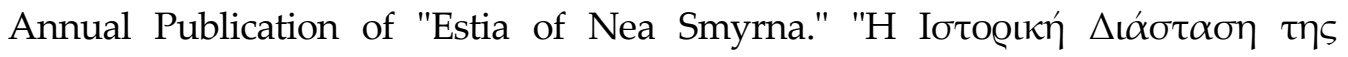

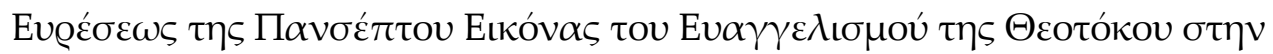

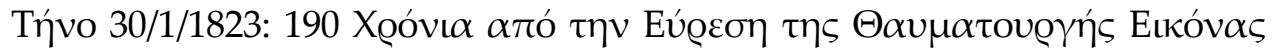

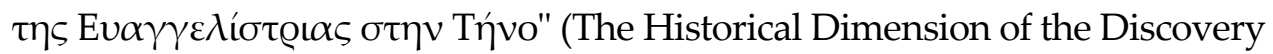
of the All-Venerable Icon of the Annunciation of the Theotokos on Tinos 30 January 1823: 190 Years from the Discovery of the Miracle-Working Icon of

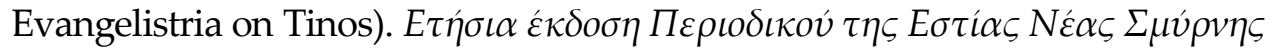
89 (2012): 18-24.

Behr, Carl A. P. Aelius Aristides, The Complete Works; Volume II: Orations XVII-LIII. Leiden: Brill, 1981.

Bittrich, Ursula. Traum-Mantik-Allegorie: Die Hieroi Logoi des Aelius Aristides im weiteren Kontext der griechisch-römischen Traumliteratur (Dream Manty Allegory: The Hieroi Logoi of Aelius Aristides in the broader context of Greco-Roman dream literature). Berlin and Boston: Walter de Gruyter, 2017.

Chirban, John T. (Ed.). Holistic Healing in Byzantium. Brookline, MA: Holy Cross Orthodox Press, 2010.

Crisafulli, Virgil S., and Nesbitt, John W. The Miracles of St. Artemios. Leiden: Brill, 1996.

Csepregi, Ildiko. The Compositional History of Greek Christian Incubation Miracle Collections: Saint Thecla, Saint Cosmas and Damian, Saint Cyrus and John, Saint Artemios. Doctoral dissertation. Central European University, 2007.

Deubner, Ludwig. De incubatione capita quattuor (Four books concerning incubation). Leipzig and Berlin: Teubner, 1900.

_. Kosmas und Damian: Texte und Einleitung (Kosmas and Damian: Texts and Introduction). Leipzig and Berlin: Teubner, 1907.

Dillon, Matthew. "The Didactic Nature of the Epidaurian Iamata." Zeitschrift für Papyrologie und Epigraphik 101 (1994): 239-260.

Downie, Janet. At the Limits of Art: A Literary Study of Aelius Aristides' Hieroi Logoi. New York: Oxford University Press, 2013.

_. "Narrative and Divination: Artemidorus and Aelius Aristides." Archiv für Religionsgeschichte 15 (2015): 97-116.

Dubisch, Jill. "Golden Oranges and Silver Ships: An Interpretive Approach to a Greek Holy Shrine." Journal of Modern Greek Studies 6 (1988): 117-134.

_. "Pilgrimage and Popular Religion at a Greek Holy Shrine." In Religious Orthodoxy and Popular Faith in European Society, edited by Ellen Badone, 113139. Princeton: Princeton University Press, 1990.

. "Men's Time and Women's Time: History, Myth, and Ritual at a Modern Greek Shrine." Journal of Ritual Studies 5 (1991): 1-26.

. In a Different Place: Pilgrimage, Gender, and Politics at a Greek Island Shrine. Princeton: Princeton University Press, 1995.

Duffy, John. "Some Observations on Sophronius' Miracles of Cyrus and John." Journal of Theological Studies 35 (1984): 71-90. 
Edelstein, Emma, and Edelstein, Ludwig. Asclepius: A Collection and Interpretation of the Testimonies, 2 vols. Baltimore: Johns Hopkins University Press, 1988. [First edition: Baltimore: Johns Hopkins University Press, 1945].

Efthymiadis, Stephanos, Déroche, Vincent, with contributions by André Binggeli, and Zissis Aïnalis. "Greek Hagiography in Late Antiquity (Fourth-Seventh Centuries)." In The Ashgate Research Companion to Byzantine Hagiography, Vol. 1: Periods and Places, edited by Sthephanos Efthymiadis, 35-94. Aldershot: Ashgate, 2011.

Forsen, Björn. Griechische Gliederweihungen. Eine Untersuchung zu ihrer Typologie und ihrer religions- und sozialgeschichtlichen Bedeutung (Greek link consecrations. An investigation on their typology and its religious and social historical significance). Helsinki: Papers and Monographs of the Finnish Institute at Athens, 1996.

Graham, Emma-Jayne. "Anatomical Votive Reliefs as Proof for Specialisation at Ancient Greek Healing Sanctuaries?." The Votives Project. Last modified May 4, 2017. Retrieved from https://bit.ly/2wj2U9O.

Håland, Evy Johanne. "The Dormition of the Virgin Mary, on the Island of Tinos: A Performance of Gendered Values in Greece." The Journal of Religious History 36 (2012): 89-117.

_. "From the Ritual Year of the Miraculous Icon on the Greek Island of Tinos to the Wider Mediterranean." Comparative Civilizations Review 63 (2010): 19-36. "The Ritual Year of the Icon of the Annunciation on the Island of Tinos, Greece." Folklore: Electronic Journal of Folklore 47 (2011): 91-112.

_. Greek Festivals, Modern and Ancient: A Comparison of Female and Male Values, 2 vols. Newcastle upon Tyne: Cambridge Scholars Publishing, 2017.

Harvey, F. David. "Literacy in the Athenian Democracy." Revue des Études Grecques 79 (1966): 585-635.

Herzog, Rudolf. Die Wunderheilungen von Epidauros: Ein Beitrag zur Geschichte der Medizin und der Religion (The Miracle Healing of Epidaurus: A Contribution to the History of Medicine and Religion). Leipzig: Dieterichsche Verlagsbuchhandlung, 1931.

Israelowich, Ido. Society, Medicine and Religion in the Sacred Tales of Aelius Aristides. Mnemosyne. Supplement volume, 341. Leiden: Brill, 2012.

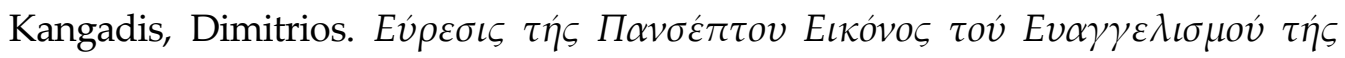

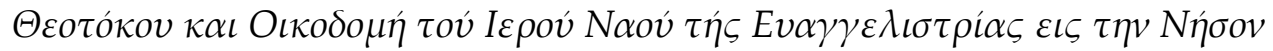
Tívov (Discovery of the All-Venerable Icon of the Annunciation of the Mother of God and the Establishment of the Holy Church of Evangelistria on the Island of

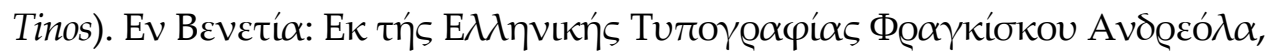
1833.

Kee, Howard C. "Aretalogy and Gospel." Journal of Biblical Literature 92 (1973): 402-422.

Konstan, David, and Dillon, Matthew. "The Ideology of Aristophanes' Wealth." The American Journal of Philology 102 (1981): 371-394. 


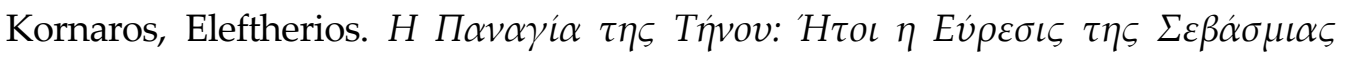

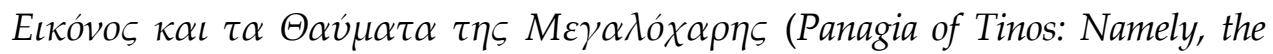
Discovery of the Revered Icon and the Miracles of the Megalochari). AӨnvat:

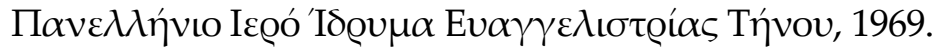

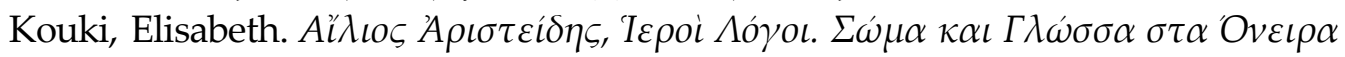

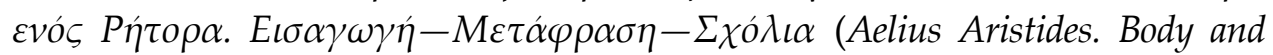
Language in the Dreams of an Orator. Introduction-Translation-Commentary).

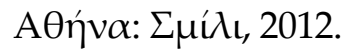

Krueger, Derek. "Christian Piety and Practice in the Sixth Century." In The Cambridge Companion to the Age of Justinian, edited by Michael Maas, 291-315. Cambridge: Cambridge University Press, 2005.

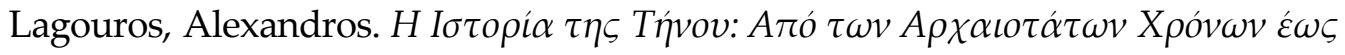
$\Sigma \eta \mu \varepsilon \rho o v$ (The History of Tinos: From the Most Ancient Times up to the Current Day). AӨற́vat: Tи́vos, 1965.

LiDonnici, Lynn R. Tale and Dream: The Text and Compositional History of the Corpus of Epidaurian Miracle Cures. Doctoral thesis. University of Pennsylvania, 1989. . "Compositional Background of the Epidaurian 'Iamata'." The American Journal of Philology 113 (1992): 25-41.

—. The Epidaurian Miracle Inscriptions: Text, Translation and Commentary. Texts and Translations, no. 36. Atlanta: Society of Biblical Literature, 1995.

Melfi, Mileni. Il santuari di Asclepio in Grecia. Studia Archaeologica (The sanctuary of Asclepius in Greece. Studia Archaeologica), no. 157. Roma: L'Erma di Bretschneider, 2007.

Oberhelman, Steven M. (Ed.). Dreams, Healing, and Medicine in Greece: From Antiquity to the Present. London: Ashgate, 2013.

_. "Anatomical Votive Reliefs as Evidence for Specialization at Healing Sanctuaries in the Ancient Mediterranean World." Athens Journal of Health 1 (2014): 47-62.

_. "Interpretations of Signs and Dreams: Greek Christian Traditions." In Prophecy and Prognostication in Medieval European and Mediterranean Societies, edited by Matthias Heiduk. Berlin: Walter de Gruyter, forthcoming.

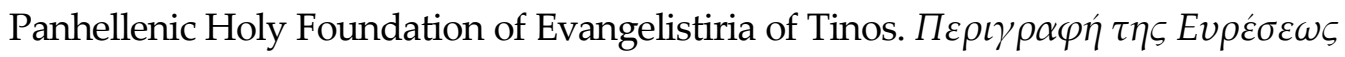

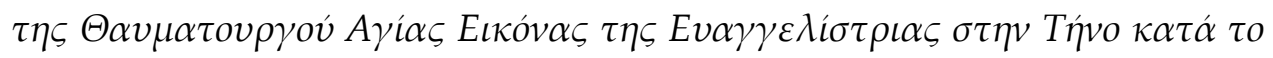

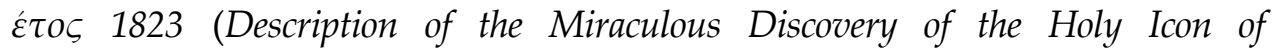

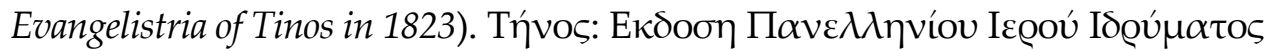

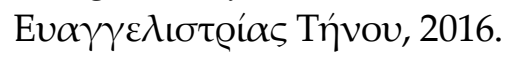

Parry, Ken (Ed.). The Blackwell Dictionary of Eastern Christianity. Oxford: Blackwell, 1999.

Pearcy, Lee T. "Theme, Dream, and Narrative: Reading the Sacred Tales of Aelius Aristides." Transactions of the American Philological Association 118 (1988): 377391.

Pfohl, Gerhard. Inschriften der Griechen. Epigraphische Quellen zur Geschichte der Antiken Medizin (Inscriptions of the Greeks. Epigraphic sources on the history of 
ancient medicine). Darmstadt: Wissenschaftliche Buchgesellschaft Darmstadt, 1977.

Reithmüller, Jürgen. Asklepios: Heiligtümer und Kulte (Asklepios: sanctuaries and cults), 2 vols. Heidelberg: Verlag Archäologie und Geschichte, 2005.

Renberg, Gil H. "Public and Private Places of Worship in the Cult of Asclepius at Rome." Memoirs of the American Academy in Rome 51/52 (2006/2007): 87-172.

_. "Was Incubation Practiced in the Latin West?." Archiv für Religionsgeschichte 8 (2016): 104-147.

Where Dreams May Come: Incubation Sanctuaries in the Greco-Roman World, 2 vols, Religions in the Graeco-Roman World, no. 184. Leiden: Brill, 2017.

Roebuck, Carl. Corinth, Volume XIV: The Asklepieion and Lerna. Princeton: American School of Classical Studies at Athens, 1951.

Rogers, Rebecca. "Learning to Be Good Girls and Women: Education, Training and Schools." In The Routledge History of Women in Europe since 1700, edited by Deborah Simonton. Abingdon and New York: Routledge, 2006.

Steger, Florian. Asklepios: Medizin und Kult (Asklepios: medicine and cult). Stuttgart: Franz Steiner Verlag, 2017.

Tagliabue, Aldo. "An Embodied Reading of Epiphanies in Aelius Aristides Sacred Tales." Ramus 45 (2016): 213-230.

Talbot, Anne-Marie. "Pilgrimage to Healing Shrines: The Evidence of Miracle Accounts." Dumbarton Oaks Papers 56 (2002): 153-173.

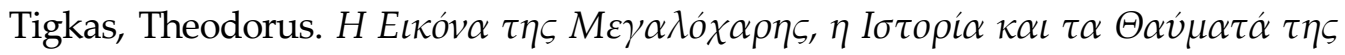

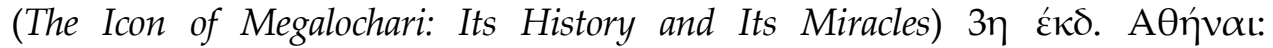

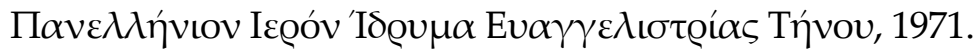

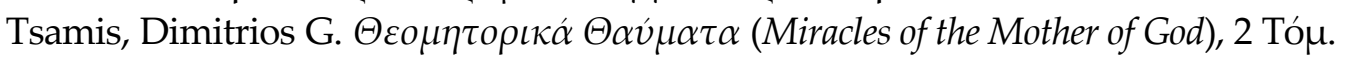

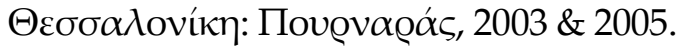

van D. Ploeg, Ghislaine. The Impact of the Roman Empire on the Cult of Asclepius. Oxford: Oxford University Press, 2019.

van der Eijk, Philip. "Divination, Prognosis and Prophylaxis: The Hippocratic Work 'On Dreams' (De Victu 4) and Its Near Eastern Background." In Magic and Rationality in Ancient Near Eastern and Graeco-Roman Medicine, edited by Herman Horstmanshotl and Marten Stol, 187-218. Leiden: Brill, 2004.

van Straten, Folkert T. "Gifts for the Gods." In Faith, Hope and Worship. Aspects of Religious Mentality in the Ancient World, edited by Henk S. Versnel, 65-151. Leiden: Brill, 1981.

Versnel, Henk. Coping with the Gods: Wayward Readings in Greek Theology. Leiden: Brill, 2011.

Wickkiser, Bronwen L. Asklepios, Medicine and the Politics of Healing in Fifth-Century Greece: Between Craft and Cult. Baltimore: Johns Hopkins University Press, 2008.

Wisniewski, Robert. The Beginnings of the Cult of Relics. Oxford: Oxford University Press, 2018. 